\title{
RADIOCARBON-BASED CHRONOLOGY OF THE PALEOLITHIC IN SIBERIA AND ITS RELEVANCE TO THE PEOPLING OF THE NEW WORLD
}

\author{
Sergey A Vasil'ev ${ }^{1} \cdot$ Yaroslav V Kuzmin $^{2} \cdot$ Lyubov A Orlova $^{3} \cdot$ Vyacheslav N Dementiev $^{4}$
}

ABSTRACT. The territory of Siberia is of crucial importance for the study of early human dispersal and the peopling of the New World. A Siberian Paleolithic Radiocarbon Database has been compiled. The Database allows us to compile a chronolgical framework for human colonization of Northern Asia. There are $446{ }^{14} \mathrm{C}$ dates for 13 Middle and 111 Upper Paleolithic sites older than around 12,000 BP. Seventeen percent of the dates were obtained by the accelerator mass spectrometry (AMS) technique, and the remaining $83 \%$ are conventional. From the viewpoint of the spatial distribution of the ${ }^{14} \mathrm{C}$-dated sites, the majority of these are located at the Yenisey River Basin, Transbaikal, and the Altai Mountains. The general outline of the Upper Paleolithic colonization of Siberia is given here. The earliest traces of modern human occupation are dated to around 43,000-39,000 BP in the southern part of Siberia. It seems that by around 13,000 BP, almost all of northern Asia, including the extreme northeastern Siberia had been colonized by modern humans. We discuss some controversial problems that have provoked heated debates in current Russian archaeology. Notable among these are the surprisingly early AMS dates for the Early Upper Paleolithic, the age of the Dyuktai culture of Yakutia, the problem of human presence in Siberia at the time of the Last Glacial Maximum (20,000-18,000 BP), and the timing of the initial settling of the Chukchi Peninsula and northeastern Siberia.

\section{INTRODUCTION}

The territory of Siberia (or northern Asia; Figure 1) has attracted the attention of students of prehistory for many years. This area is of crucial importance to questions regarding the first entry of people to the New World, human-land relationship in periglacial environments, and prehistoric culture contacts in the northern Pacific. In light of new data, we discuss here the peopling of Siberia and the timing of the initial human entry into the Americas. We also discuss the controversial subject of the age of the Dyuktai culture of Yakutia.

The establishment of a firm chronological framework for the Paleolithic in Siberia is of direct relevance to the complicated issue of the initial peopling of the New World. In this work, we use radiocarbon $\left({ }^{14} \mathrm{C}\right)$ dates obtained mostly on the Upper Paleolithic sites (and few Middle Paleolithic ones) in Siberia since 1960. Several summaries of Siberian prehistoric ${ }^{14} \mathrm{C}$ dates have been published in English (see, e.g., Henry 1984; Kuzmin 1994; Kuzmin and Tankersley 1996; Kuzmin and Orlova 1998). The recent Russian monograph on the ${ }^{14} \mathrm{C}$ chronology of the Paleolithic of Russia includes 423 dates from Siberia (Lisitsyn and Svezhentsev 1997). Because the New World in general, and Alaska in particular, was already colonized at minimum around 12,000 BP (cf., West 1996), we excluded Siberian Paleolithic and Initial Neolithic ${ }^{14} \mathrm{C}$ dates younger than around 12,000 BP compared with previously published summaries (Lisitsyn and Svezhentsev 1997; Kuzmin and Orlova 1998; Orlova et al. 2000b, Kuzmin 2000).

In this paper, we present the updated ${ }^{14} \mathrm{C}$ Database of the Siberian Paleolithic with values earlier than around 12,000 BP (Table 1). One should bear in mind that in a number of cases the assemblages included in our roster (the Elenev Cave, Layer 18 and underlying deposits; Novoselovo 6, Maynin-

\footnotetext{
${ }^{1}$ Institute for the Material Culture History, Russian Academy of Sciences, 18 Dvortsovaia Emb., St.-Petersburg 191186, Russia. Email: anna@neuro.pri.pu.ru

${ }^{2}$ Pacific Institute of Geography, Far Eastern Branch of the Russian Academy of Sciences, 7 Radio St., Vladivostok 690041, Russia. Email: ykuzmin@ tig.dvo.ru

${ }^{3}$ Institute of Geology, Siberian Branch of the Russian Academy of Sciences, 3 Koptyug Ave., Novosibirsk 630090, Russia. Email: orlova@uiggm.nsc.ru

${ }^{4}$ Center for GIS Technologies, Siberian Branch of the Russian Academy of Sciences, 3 Koptyug Ave., Novosibirsk 630090, Russia. Email: dementev@uiggm.nsc.ru
} 


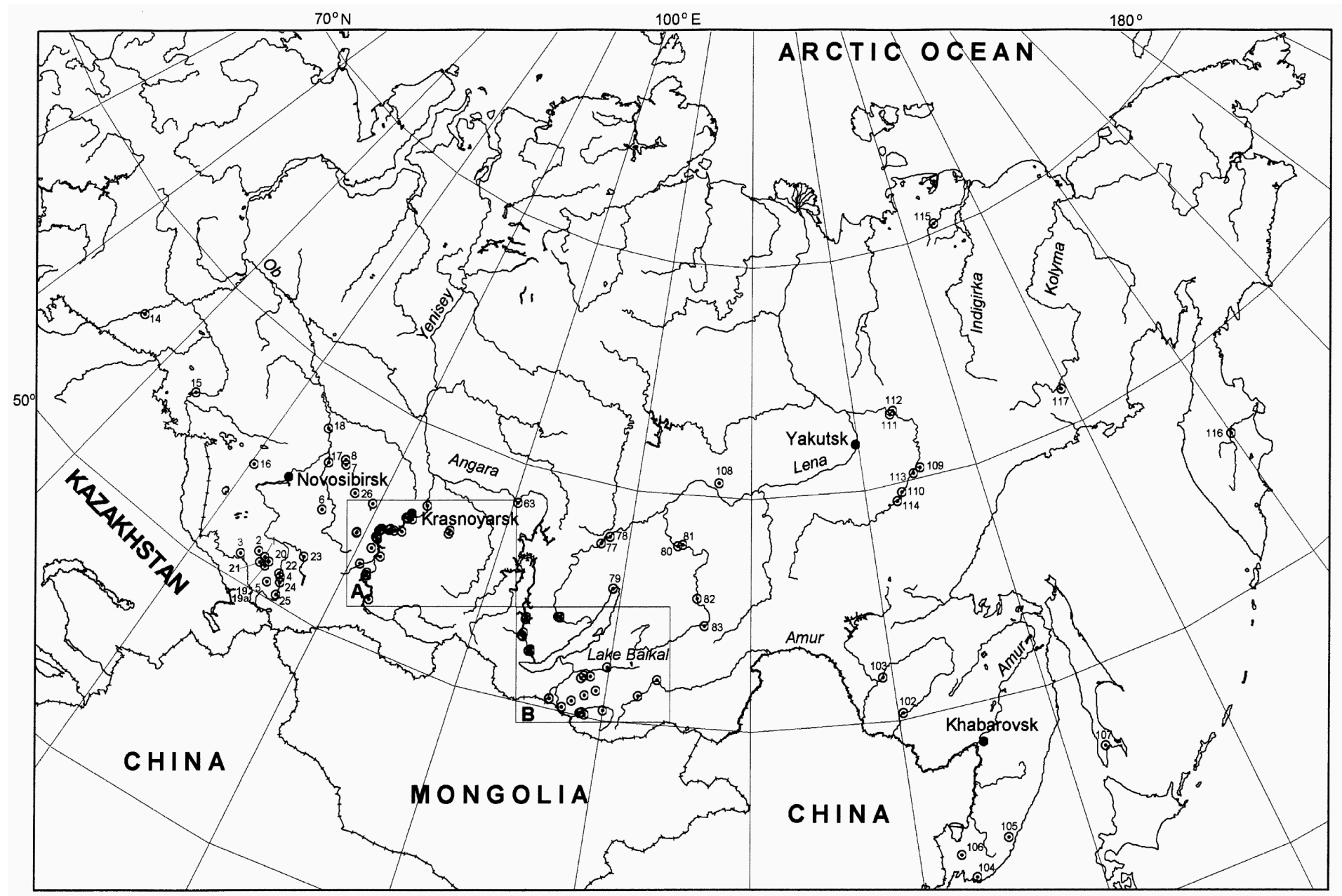

Figure 1 Radiocarbon-dated Paleolithic occurrences in Siberia 
skaya, Layers A1-A3; Bolshoi Yakor 1, Layers 5 and 6; Ust'-Kyakhta 17; Studenoe 1; Malye Kuruktachi; Berelekh; Ushki; Siberdik, Layer 3), also produced dates younger than 12,000 BP, some of which are not included to the Table 1 (see appendix). Data presented are as of May 2001. In the columns "Latitude" and "Longitude", the geographic coordinates are given as decimal values (i.e., 70.50 means $70^{\circ} 30^{\prime}$ ) for using the Geographic Information System software, such as ARC/VIEW and ARC/INFO.

\section{${ }^{14} \mathrm{C}$ DATABASE OF THE SIBERIAN PALEOLITHIC}

Discussion of Siberian Paleolithic chronology in this paper is based on the ${ }^{14} \mathrm{C}$ dates directly associated with the Paleolithic assemblages. Thus, we omitted dates from paleontological localities without clear evidence of human presence, and dates from geological cross-sections located near the Paleolithic sites. For example, for the site of Berelekh in northeastern Siberia only ${ }^{14} \mathrm{C}$ dates from the cultural layer of the habitation site are included in the list (Table 1). The same is true for dates from archaeological occurrences run on samples lacking direct association with artifacts, for instance Filimoshki (Kuzmin 1996:138). At the same time, some dates included in the list (Afontova 2, GIN-117; Kashtanka 1, GrN-24482 and GrN-24481; Kunaley, GIN-6124; Gorbatka 3, SOAN1922; and Ust'-Mil 2, LE-955) were run on samples lying below the artifact-bearing strata, thus providing only lower temporal limit for the assemblages. Some dubious Pleistocene-age ${ }^{14} \mathrm{C}$ dates of the apparently Holocene (Neolithic and Bronze Age) cultural strata, mostly from the Transbaikal (cf., Konstantinov 1994), are excluded. The ${ }^{14} \mathrm{C}$ dates, mentioned in the literature without indication of laboratory numbers and/or standard deviation, are also omitted. Finally, there are a lot of disappointing inaccuracies in individual data presentation in literature. Thus, we use the ${ }^{14} \mathrm{C}$ dates as these appeared in first publications.

As a result of careful dates selection, we roster 13 Middle and 111 Upper Paleolithic localities, which produced 446 dates (Table 1). Slightly more than $17 \%$ of the dates were obtained using accelerator mass spectrometry (AMS) technique; others are conventional. Largest ${ }^{14} \mathrm{C}$ datasets are known from the Shestakovo (21 values); Malta (19); Mayninskaya and Bolshoi Yakor 1 (15 for each one); Ust'-Karakol 1, and Ikhine 2, and Afontova Gora 2 (13 for each one); Geographical Society Cave (11); Kara-Bom and Kamenka 1 (10 for each one) sites. From the geographical viewpoint, the distribution of sites is no less uneven (Figure 1). The majority of the ${ }^{14} \mathrm{C}$-dated sites locate in the Yenisey River drainage area and adjacent regions (33\%) (Figure 2), Altai Mountains and the Kuznetsky Basin (19\%), Transbaikal (14\%), and areas around the Lake Baikal (9\%) (Figure 3). At the same time, some areas extremely rich in prehistoric remains, such as the Angara and Upper Lena River valleys, yielded insufficient data compared to the number of sites (only $11 \%$ of total dates). Vast territories of the southern part of Northeastern Siberia (6\%), the Russian Far East (less than 6\%) and the West Siberian Plain (3\%) produced only a few dates.

\section{${ }^{14} \mathrm{C}$ DATING OF BONE COLLAGEN FROM SIBERIAN PALEOLITHIC SITES}

The reliability of ${ }^{14} \mathrm{C}$ dates, made on animal and human bones, has been a complicated problem for decades (cf., Taylor 1997:87-91). There is a clear skepticism from some sources about the accuracy of bone ${ }^{14} \mathrm{C}$ dates made in Russian laboratories (cf., Goebel 1993:139-40). However, we are quite confident that the technique of collagen extraction developed in Russia (Arlsanov 1987:137-43; Sulerzhitsky 1997) is very reliable. The general idea is that slow dissolution of the mineral part of whole pieces of bones in diluted hydrochloric acid allows one to extract non-contaminated collagen, and to see the degree of preservation of initial fiber-like internal collagen structure after demineralization. This is different from widely accepted Longin's (1971) technique of collagen extraction, 


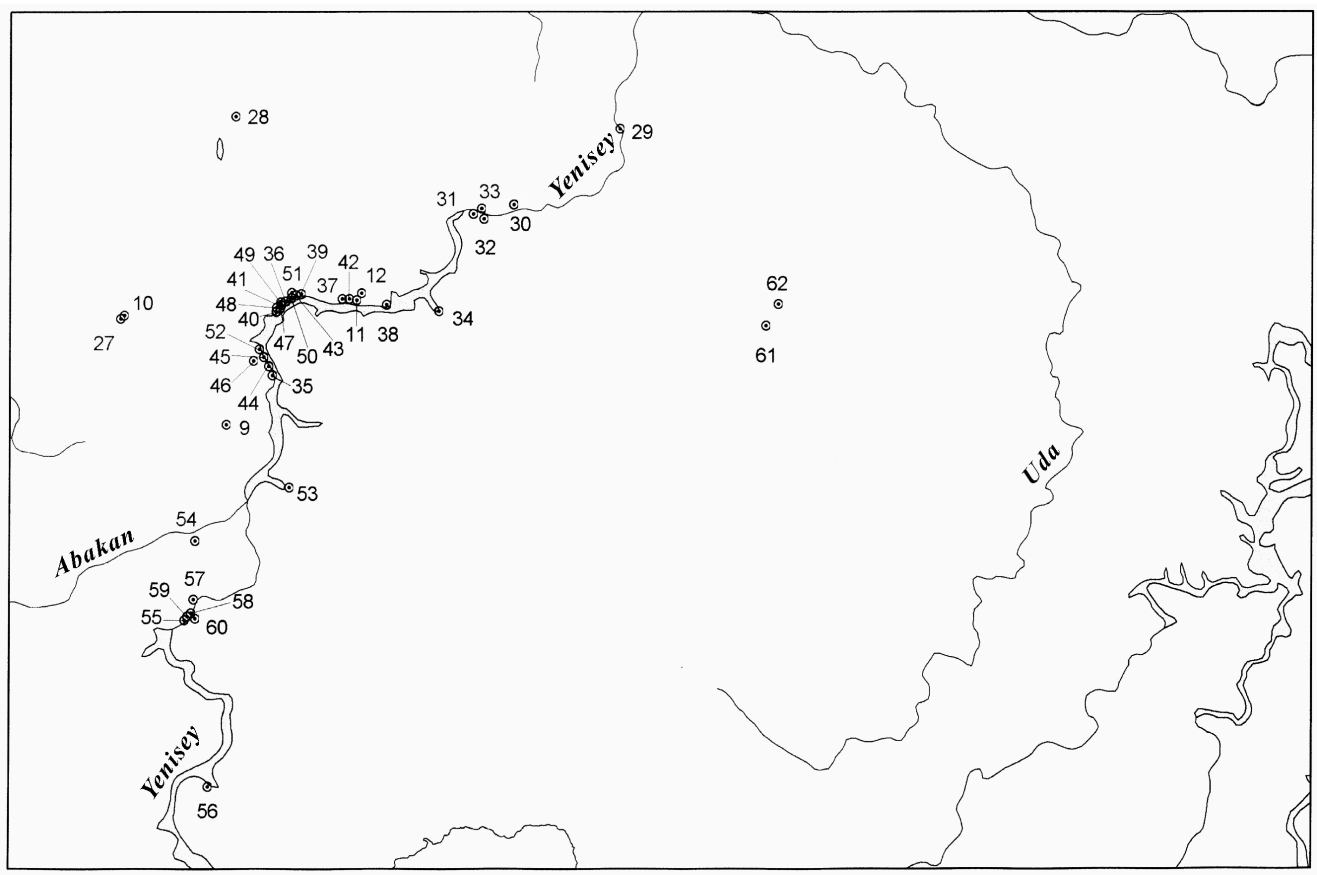

Figure 2 Radiocarbon-dated Paleolithic occurrences near the Yenisey River

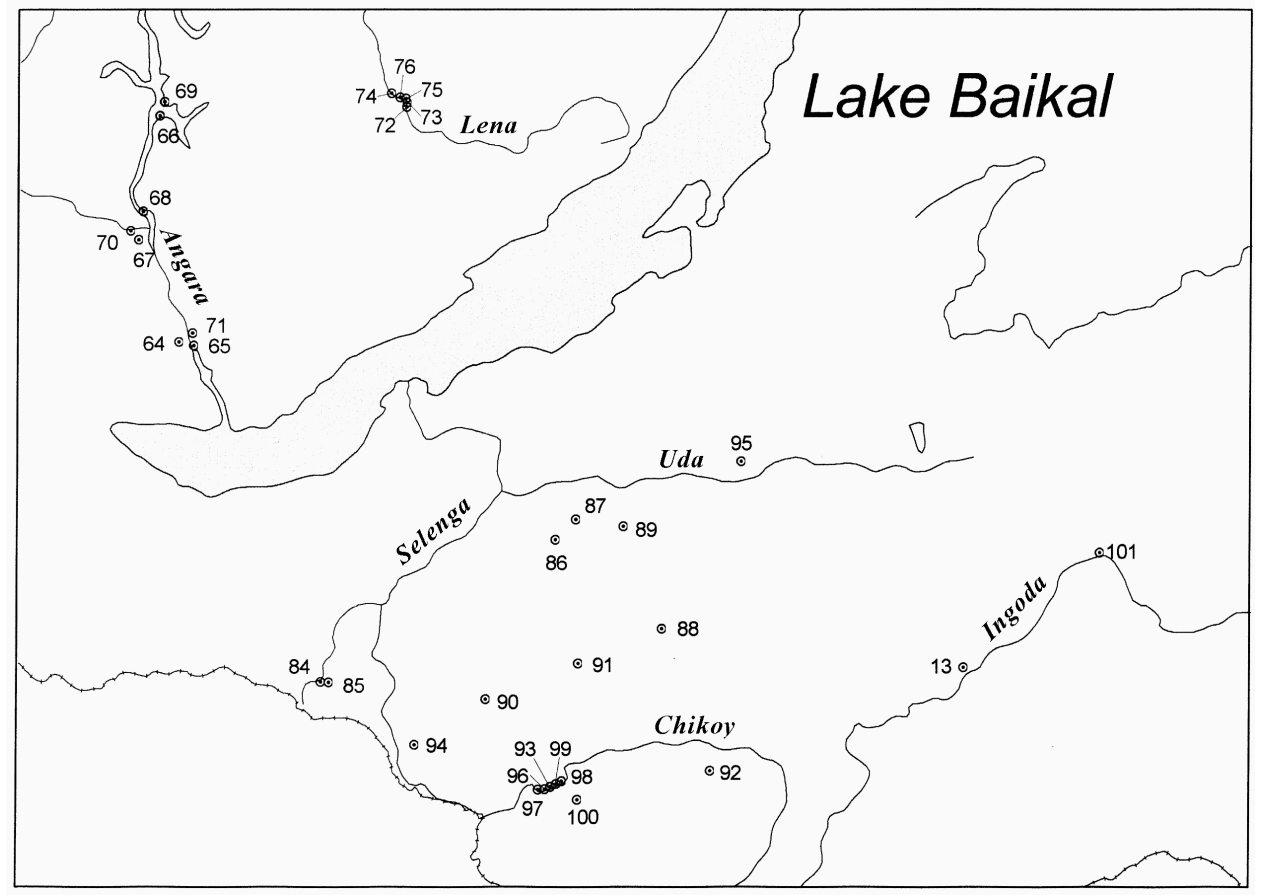

Figure 3 Radiocarbon-dated Paleolithic occurrences near Lake Baikal 
where bone material is powdered before demineralization. The reliability of the slow dissolution technique for collagen extraction is supported by parallel dating of the same pieces of bone in Moscow (Geological Institute, Russian Academy of Sciences), and in the NSF-Arizona AMS Facility at the University of Arizona (Tucson, Arizona, USA) (Vasil'chuk et al. 2000) and Beta Analytic, Inc. (Miami, Florida, USA) (MacPhee et al. 2002).

The following technique of collagen extracted has been used at the Novosibirsk ${ }^{14} \mathrm{C}$ laboratory (lab code SOAN) since 1985. The pieces of bones 10-20 cm long, once cleaned of any surface compounds, are demineralized by $5 \% \mathrm{HCl}$ solution (the proportion is $7-8 \mathrm{~L}$ of solution for $1 \mathrm{~kg}$ of bones) under a temperature of $2-3{ }^{\circ} \mathrm{C}$, usually in a refrigerator. As the surface layer becames soft, once every few days it was scraped with a knife, and the demineralization continued until the mineral part of bone was completely dissolved; sometimes this may take 1-2 weeks. Finally, the extracted gelatin-like collagen is thoroughly washed by distilled water. To remove the humic acids, the collagen is treated by a $0.1 \mathrm{~N}$ solution of $\mathrm{NaOH}$ for several hours. The remaining collagen is again washed by distilled water, dried, and carbonized by heating on $800{ }^{\circ} \mathrm{C}$ in oxygen-free environ-

ment. To remove the phosphorous compounds, carbonized collagen is treated with a mixture of $\mathrm{HNO}_{3}$ and $\mathrm{HCl}$ ("aqua regia"). Finally, the cleaned collagen is washed by distilled water, dried, and used for benzene preparation.

In some laboratories (such as Geological Institute, Moscow, lab code GIN) centrifuging is used for separation of humic acids from collagen (acceleration of 2500-3000 g). As for any bacterial contamination remaining after collagen extraction, repeated washing by distilled water ensures the removal of all possible bacteria (L D Sulerzhitsky, personal communication 2000).

Thus, the extracted collagen and the ${ }^{14} \mathrm{C}$ dates run on it seem to be very reliable, and there have been no serious arguments so far against the accuracy of the extraction technique. The key issue is that if collagen is already degraded before sampling, there is no way to obtain reliable material for dating, even if separate amino acids are being used as a source of ${ }^{14} \mathrm{C}$ (cf., Stafford et al. 1991). As one can observe after bone demineralization by cold $\mathrm{HCl}$, well-preserved collagen keeps the fiber-like structure but the degraded collagen usually has "amorphic" appearance.

Several examples of the reliability of such collagen extraction may be found in Sulerzhitsky (1997: 186-8). One of the best cases is dating of several woolly mammoth bones from Taymyr Peninsula (extreme northern Siberia), collected on the surface and partly covered with moss. After mechanical removal of moss and collagen extraction as described above, the Late Glacial ${ }^{14} \mathrm{C}$ ages (around $12,000 \mathrm{BP}$ ) were obtained. This clearly shows that well-preserved collagen is very resistant to any kind of contamination.

\section{EVALUATION OF ${ }^{14} \mathrm{C}$ DATES IN SIBERIAN PALEOLITHIC GEOARCHAEOLOGY}

The critical evaluation of a large series of ${ }^{14} \mathrm{C}$ dates has put forward the concept of "practicable accuracy" of ${ }^{14} \mathrm{C}$ dating of archaeological assemblages (Krenke and Sulerzhitsky 1992; see for details Kuzmin and Orlova 1998:24-5). The limit in accuracy of ${ }^{14} \mathrm{C}$ dating of the Paleolithic sites, being a part of the "practicable accuracy" concept, has been empirically estimated as $3000-4000{ }^{14} \mathrm{C}$ years (Krenke and Sulerzhitsky 1992). However, some archaeologists and geoarchaeologists are still disappointed by relatively large difference in ${ }^{14} \mathrm{C}$ date series from the same (and supposedly uniform) cultural layer. Recent examples for Siberia may be found in Goebel et al. (2000:572), and Goebel and Waters (2000). 
We argue that the age difference of several hundreds or even thousands of ${ }^{14} \mathrm{C}$ years should be expected a priori in the series of ${ }^{14} \mathrm{C}$ dates from Paleolithic sites due to the complex taphonomic nature of organic material (charcoal, uncarbonized wood, bones, etc.) to be dated. This essentially means that a large (up to $3000-4000{ }^{14} \mathrm{C}$ years) difference in the date series from single cultural layer of a Paleolithic site should not confuse archaeologists, because it was observed on many welldated sites with non-disturbed stratigraphy.

It seems that Paleolithic humans collected and brought to habitation sites wood (including fossil one), bones, antlers, tusks, and teeth of different (from the view of ${ }^{14} \mathrm{C}$ dating) ages. The dates found on mammoth bones and/or tusk should be considered with extreme caution, taking into account the possibility that the prehistoric inhabitants of a site collected these pieces from natural bone accumulations (deathsites or so-called "mammoth cemeteries"). The best controversial example is the date of around 43,000 BP obtained for the site of Druzhinikha at the Yenisey River basin of apparently Final Pleistocene age based on geological data. It should be added that some other dates included in our roster (Sabanikha, Shlenka, Pervomaiskoe 1, and Ulug-Bil') were also run on bones collected from the surface, thus these dates are controversial. In other cases, the faunal assemblages from the cave sites seem to be produced mostly by natural agencies, and the degree of human involvement is dubious (Proskuriakov Rockshelter and the Geographical Society Cave).

The site of Shestakovo in western Siberia (Zenin et al. 2000b, 2000d; Derevianko et al. 2000b) yielded evidence on scavenging of mammoth bones and teeth from the natural accumulation, and as a result ${ }^{14} \mathrm{C}$ mammoth dates show wide variation within one cultural layer, from $20,480 \pm 180 \mathrm{BP}$ to $22,340 \pm 180 \mathrm{BP}$. Multiple human occupations of the site resulted in a wide range of ${ }^{14} \mathrm{C}$ ages of charcoal, from $20,800 \pm 450 \mathrm{BP}$ to $23,250 \pm 110 \mathrm{BP}$. Another example of large variation in ${ }^{14} \mathrm{C}$ date series was obtained from the upper component of the Kostenki 1 site in central Russia, where 16 dates from the same dwelling unit vary from 20,800 \pm 300 BP to 24,100 $\pm 500 \mathrm{BP}$ (Praslov and Sulerzhitsky 1997).

Thus, we should expect that in the Paleolithic ${ }^{14} \mathrm{C}$ date series the range of dates might be quite wide, and it is almost impossible to judge which date is more reliable. This applies especially to sites where only woolly mammoth bones have been ${ }^{14} \mathrm{C}$-dated. The general approach is that charcoal ${ }^{14} \mathrm{C}$ dates taken from hearth-like features could give us the age values most closely corresponding to the time of human occupation. However, such examples from Siberia are rare. Unfortunately, Paleolithic cultural layers could not be regarded as "snapshots" in terms of the age of organics recovered during the excavations and later ${ }^{14} \mathrm{C}$-dated. Careful evaluation of ${ }^{14} \mathrm{C}$ data should be given when scientists are trying to find out the timing of human occupation of the Paleolithic sites.

\section{CONTROVERSIES IN ${ }^{14} \mathrm{C}$ CHRONOLOGY OF THE UPPER PALEOLITHIC IN SIBERIA}

It is far beyond our scope here to discuss the chronology of the Upper Paleolithic in Siberia in full detail (see e.g. Larichev et al. 1988, 1990, 1992; Vasil'ev 1993; West 1996; Derevianko 1997; Kuzmin and Orlova 1998; Kuzmin et al. 1998a, 1998b; Goebel and Slobodin 1999; Orlova et al. 2000b; Kuzmin 2000). Here we wish only to mention some controversial problems connected with the problem of ${ }^{14} \mathrm{C}$ chronology of the Dyuktai culture of Yakutia, which provokes hot debates in current Russian Paleolithic archaeology.

The timing of the Dyuktai culture has been discussed several times (e.g., Abramova 1979c; Yi and Clark 1985). This issue is important because the Dyuktai culture is considered to be directly related to the initial peopling of the New World (e.g. West 1996). Mochanov (1977) proposed the age of the earliest Dyuktai sites, Ust'-Mil 2, Ezhantsy, and Ikhine 2, to be as old as around 35,000 BP 
(Table 1). Several scholars disagree with such an early age of typical microblade industry in remote northeast Siberian territory (Abramova 1979c; Kashin 1983; Yi and Clark 1985; Kuzmin and Orlova 1998). To re-evaluate the ${ }^{14} \mathrm{C}$ chronology of the earliest Dyuktai sites, we use both ${ }^{14} \mathrm{C}$ and palynological records from archaeological sites and geological Late Pleistocene sections in eastern and northeastern Siberia.

Through all the Late Pleistocene sections in northern part of Siberia, the distinct feature is the predominance of arboreal (tree) pollen in deposits dated to around 30,000-25,000 BP, and predominance of non-arboreal pollen (grasses) and spores in deposits dated to around 33,000-30,000 BP and around 22,000-18,000 BP (cf. Kind 1974). The most complete record of climatic fluctuations in the second part of Late Pleistocene in northern Siberia was obtained from the Molotkovsky Kamen section in the lower stream of the Kolyma River (latitude $68^{\circ} 00^{\prime} \mathrm{N}$, longitude $163^{\circ} 00^{\prime} \mathrm{E}$ ), based on palynological and ${ }^{14} \mathrm{C}$ data (Kaplina and Lozhkin 1982; Kaplina and Giterman 1983; Giterman 1985). In total, about $15{ }^{14} \mathrm{C}$ dates and about $70-80$ pollen spectra were obtained for the Molotkovsky Kamen section. Two warm climatic episodes with a predominance of arboreal pollen (up to $40-60 \%$ of the total amount of pollen and spores) were ${ }^{14} \mathrm{C}$-dated to around 43,000-34,500 BP and around 28,000-24,500 BP. Vegetation during those times was represented by birch-larch forests. Two cold episodes with an increase in non-arboreal pollen and spore content (up to $80 \%$ of the total amount) were ${ }^{14} \mathrm{C}$-dated to around 34,000-28,000 BP and around 24,000-18,000 BP. Vegetation was presented by tundra, with small admixture of larch (sparse forest-tundra associations). The same features in the pollen spectra were recognized in the records from Chuiskoye and Vilyi crosssections in Central Yakutia (Shofman et al. 1977; Alekseev et al. 1986).

Several early Dyuktai sites, such as Ust'-Mil 2, Ikhine 2, and Ezhantsy, also produced pollen records (Savvinova et al. 1996). At Ust'-Mil 2, in the lower (i.e. pre-cultural) part of the section at a depth of $4.00 \mathrm{~m},{ }^{14} \mathrm{C}$-dated to $35,600 \pm 900 \mathrm{BP}$ (LE-965), the amount of arboreal pollen is about $11-39 \%$. In the upper part of section with the Dyuktai culture artifacts at a depth of $1.75-2.50 \mathrm{~m},{ }^{14} \mathrm{C}$-dated to around 23,500-30,000 BP, the amount of arboreal pollen decreases dramatically, and does not exceed 5-10\% of total pollen and spores content. This fact could be interpreted as a reflection of the climatic deterioration. The next increase in arboreal pollen content on the Ust'-Mil 2 pollen diagram (up to $70 \%$ of total pollen and spores) is ${ }^{14} \mathrm{C}$-dated to $12,200 \pm 170 \mathrm{BP}$ (LE-953).

Thus, in the Ust'-Mil 2 pollen records the time interval between around 33,000 BP and around 23,500 BP corresponds to a cold climatic event. However, in the Molotkovsky Kamen sequence this time is characterized by dominance of arboreal pollen, which reflects climatic amelioration. Only in the upper part of the Molotkovsky Kamen section, ${ }^{14} \mathrm{C}$-dated between around 24,500 BP and around $10,000 \mathrm{BP}$, the dominance of non-arboreal pollen is noted. It should be stressed that similar features of very low arboreal pollen content are observed on the pollen diagrams of Ezhantsy, Ikhine 1, and Ikhine 2 (Savvinova et al. 1996). ${ }^{14} \mathrm{C}$ dates for those sites are more than around 16,600 BP (Ikhine 1), around 17,200 BP (Ezhantsy), and around 31,200 BP to 24,300 BP (Ikhine 2).

On the basis of pollen and ${ }^{14} \mathrm{C}$ records obtained from the Late Pleistocene sections in northern Siberia, along with critical re-examination of the Dyuktai culture records, we can assume that the portion of Ust'-Mil 2 section with low content of arboreal pollen corresponds to the final Karginsky Interglacial, ${ }^{14}$ C-dated to around 30,000-24,000 BP (see details in Kuzmin and Orlova 1998: 35-39). The use of driftwood from older deposits by the earliest Dyuktai culture bearers could result in distortion of the ${ }^{14} \mathrm{C}$ age determinations of human occupation (sic!) (cf. Kuzmin and Orlova 1998).

In this case, bone material might be more reliable in the age estimation of the Dyuktai culture rather than driftwood, which can be re-deposited from older sediments of the Aldan River. The most suit- 
able ${ }^{14} \mathrm{C}$ value from the Ikhine 2 site seems to be $26,030 \pm 200 \mathrm{BP}$ (IM-239) (Figure 4). However, the wood sample from the same depth yielded very close ${ }^{14} \mathrm{C}$ date, 26,500 $\pm 540 \mathrm{BP}(\mathrm{IM}-202)$. Nevertheless, the older ${ }^{14} \mathrm{C}$ values from the depth of $0.90-1.20 \mathrm{~m}$ between around 31,200 BP and around $27,400 \mathrm{BP}$ could be considered as less reliable. The youngest wood ${ }^{14} \mathrm{C}$ date, $24,500 \pm 480 \mathrm{BP}$ (IM203), might be more reliable.

\section{MODERN HUMAN DISPERSAL IN NORTHERN ASIA: AN OUTLINE}

The earliest known Upper Paleolithic occurrences in Siberia are dated to around 43,000-38,500 BP (Table 1). These are concentrated mostly at two areas in southern Siberia, at the Altai Mountains (Kara-Bom, Kara-Tenesh, Ust'-Karakol 1, etc.) and the Transbaikal (Tolbaga, Kamenka 1, etc.). At the same time, some occurrences at the Yenisey, Angara, and Upper Lena River basins witness the occupation of the whole southern Siberia. It seems to be premature to analyze the problem of the Upper Paleolithic genesis, associated with early Homo sapiens sapiens migration on the basis of the scanty data at hand. The earliest Upper Paleolithic traditions of Siberia share a lot of features in common with preceding Mousterian, thus demonstrating an apparent continuity between the Middle and Upper Paleolithic (Goebel et al. 1993). At the same time, these traditions evidenced the appearance of such typical Upper Paleolithic culture manifestations as mobile art objects, sophisticated bone technology, and personal ornaments. The southwestern way for early Homo sapiens sapiens migration seems to be plausible, and the Early Upper Paleolithic sites dated to the second part of the Karginsky Interglacial, around 40,000-25,000 BP, are identified at Altai Mountains, Angara River basin, and Transbaikal.

The data at hand indicate the sparse traces of humans during the final phase of the Karginsky Interglacial, around 30,000-25,000 BP. This scarcity of data could be explained by the large-scale erosion and cryoturbation of deposits during the advent of the Sartan Glaciation at around 25,00022,000 BP. Meanwhile, we could argue about the permanent colonization of south Siberian mountainous areas, from the Altai to the Transbaikal, during the Early Upper Paleolithic.

The accidental discovery of the Upper Paleolithic artifacts in such a remote area as the northern part of the Chukchi Peninsula (Laukhin et al. 1989) led to speculation about human settlement in extreme northeastern Siberia during the warm phases of the Karginsky Interglacial. However, the age estimates and stratigraphic situation for the Kymyneikei site in the northern Chukchi Peninsula remains unclear (Goebel and Slobodin 1999:125; Orlova et al. 2000b:407-8). More data have been obtained for the Yakutia. Taking into consideration the age estimates for the Dyuktai culture, we can assume that modern people settled at this territory at least at around 18,000 BP (Verkhne-Troitskaya), and perhaps earlier, about around 25,000 BP (Ikhine 2).

The data referring to the Early Sartan Glaciation, around 25,000-22,000 BP, are more numerous. Unfortunately, all these data seem to be insufficient for a reconstruction of human dispersal in details. The idea of depopulation of Siberia under the harsh climatic conditions of the peak of Sartan Glaciation at around 19,000-16,000 BP was first put forward by Tseitlin (1979), and later by Goebel (1999). In spite of inevitable decrease of an area inhabited and population movements southwards, we could argue that even during the Late Glacial Maximum, around 20,000-18,000 BP, the occupation of southern Siberia and the Russian Far East was not interrupted. Stratigraphic columns of such sites as Shlenka, Ui 1, Krasny Yar 1, Varvarina Gora, etc. provide evidence. Also, at least 14 wellstudied Upper Paleolithic sites in northern Asia have ${ }^{14} \mathrm{C}$ dates within time interval of around 20,000-18,000 BP (Table 1). 
The Final Pleistocene provides evidence of dense population at all main drainage basins in southern Siberia. Beyond more familiar areas of the Altai Mountains-Yenisey, Angara, and Upper Lena River basins, and Transbaikal - the Late Sartan time span saw human dispersal in the southern portion of the West Siberian Plain, and along the Yenisey River valley downstream from modern Krasnoyarsk. Certainly, the most important event was human dispersal in northeastern Asia along the main rivers of Yakutia. Even such remote areas as the Indigirka River basin were inhabited in the Final Pleistocene (Berelekh site). This important movement resulted in peopling of Beringia at around 12,000 BP (see below), thus continuing the general trend of human movement in northern Eurasia from southwest to northeast.

\section{BERINGIA AND THE PEOPLING OF AMERICA}

In spite of numerous efforts to search for direct ancestors of Paleoindians in northeastern Asia carried out from radically different viewpoints (cf., Mochanov 1984; Dikov 1985; Yi and Clark 1985), there is a lot to be desired in the problem of timing and tracing of the first human entry to the New World. Before discussing the archaeological evidence on Pleistocene occupation of Beringia, let us look at paleoenvironmental data relevant to the Final Sartan, i.e. the time span that is thought to witness the peopling of the New World (Kozhevnikov and Zheleznov-Chukotskii 1995). It seems that the glaciation of Chukotka was restricted by mountainous areas and glaciers could not hamper faunal and human migrations. The Bering Land Bridge existed during the entire Final Pleistocene. From 13,000 to 12,000 BP the land bridge was a vast smooth plain, whereas from 11,000 BP its area began to decrease. First, the Anadyr Strait between Chukotka and St Lawrence Island was formed; later the Bering Strait appeared. It seems that around 10,500 BP the waters of the Pacific and Arctic Oceans joined (Elias et al. 1997). Meanwhile, even after the submerging of the land bridge, the Bering Strait could not be considered as an important barrier hampering human contacts, which were possible by boats as well as on ice during winters.

The territory of Alaska was not covered by ice. Cordilleran glaciation touched parts of the Aleutian and Alaska Ranges to the south (Glaciation Park McKinley) and the modern Aleutian Islands as well as a dry shelf. The glacial lobes were oriented mostly in a southern direction, but occasional mountain glaciers penetrated the upper parts of the Yukon tributaries valleys, including the Nenana River.

The favorable conditions for animal and human dispersal existed from 11,800 to 10,500 BP during the intermediary period between glacial advances McKinley III and IV (or Riley Creek III and IV, according to the old schemes). This time span was even labeled the "Critical Millennium" of the Pleistocene. It is followed by the Park McKinley IV Phase, correlated with Younger Dryas, but persisted as late as $9500 \mathrm{BP}$.

The northern part of the area demonstrates more restricted glaciation, mostly touched the central portion of the Brooks Range (Itkillik II Phase). The last glacial advance in this region is dated around 12,800 BP, later glaciers only retreated and the time span around 11,500 BP saw significant decrease of glaciated areas. Small glaciers existed in the mountains of the southern part of the Seward Peninsular, Kuskokwim Mountains, and Yukon-Tanana Highlands. Thus the central interior Alaska, the area with intense loess deposition at Final Pleistocene, rested open for animal and human migrations (Péwé 1975; Ten Brink 1984; Bigelow 1991).

Most scholars tend to argue that cold dry steppes with sagebrush-grasses and isolated willow stands-dominated the Bering Land Bridge, while woodland refuge (willow, birch) could survive along rivers. Numerous discoveries of Pleistocene fauna (horse, bison, reindeer, wild sheep, elk, etc.) indicate that Beringia provided a favorable place for large herds of ungulates, especially during 
the so-called "Birch Zone", which evidenced a climate amelioration from 14,000 to 10,000 BP. This time span seems to correspond to the presumed human entry to the New World. The dwarf birch area gradually widened from 14,300 to 13,500 BP, across the Alaskan territory. Starting in the western portion of the Peninsular, birch distributed along the Yukon from 12,500-12,000 BP. The mountains were woodland-free with patches of herbaceous tundra. From around 11,000 BP (the late phase of the "Birch Zone") the territory saw the gradual decrease of glaciated areas and expansion of forestpoplar along river valleys, and aspen on south-facing mountain slopes. Meanwhile, herbaceous tundra still dominated the landscape. A short-term cold spell corresponding to the Younger Dryas, between 10,500 and $10,200 \mathrm{BP}$, is marked by the appearance of grass tundra in the place of bush tundra in central Alaska (Elias 2001).

As seen above, pieces of archaeological evidence relevant to prehistoric human occupation of western Beringia (the extreme northeastern Asia) are far from numerous. It has been demonstrated that central Yakutia (the Lena and Aldan valleys) were inhabited from around 24,500 to 18,000 BP. What is known is the fact that the dispersal of the Dyuktai-type culture in the central (and probably also northern) portion of Yakutia, while Berelekh evidenced human movement northwards, to the Arctic Ocean coastline around 13,000-12,000 BP.

It is more difficult to argue about the settlement of Kolyma, Kamchatka, and Chukotka, due to scarcity. The sites attributed to the Dyuktai Complex, but located beyond the core area of the culture, at the Okhotsk Sea coastal zone or the Kolyma River basin (Maiorych and Kukhtui III) are dubious. The last site is even referred to as Neolithic. In other cases, the unambiguous dates are lacking and it is difficult to judge if the sites could be referred to the Final Pleistocene or Early Holocene as in the case of the lower component of Kheta. Some sites are claimed as Paleolithic (Druchak-Vetrenyi and Uptar) received the Early Holocene ${ }^{14} \mathrm{C}$ dates. The age of the unique presumable Pleistocene site at the Kamchatka Peninsular-Ushki, remains enigmatic. There are many disappointing inaccuracies in numerous writings by Dikov on the enumeration of cultural horizons, provenance of samples for ${ }^{14} \mathrm{C}$ determinations, etc. (for latest versions see Dikov 1996a, 1996b). It seems hardly possible to make a judgement about the so-called "Ushki culture/s" that share no element in common with Siberia, as well as with North American Pleistocene assemblages. One should bear in mind that several sites (Bolshoi Elgakhchan I and II at the Omolon River, surface scatters at the Chukotka Peninsular) were referred to the Paleolithic exclusively based on the morphological similarity of the lithics found to Ushki. The age and character of the occurrences with the so-called "Pebble-tool" industries at Kamchatka and Chukotka (Orlovka II, Lopatka IV, etc.) remain far from clear. Frankly speaking, in spite of long-term research activity in the area, we have no direct evidence of the Late Pleistocene human colonization of the vast areas adjacent to the submerged portions of the Bering Land Bridge, i.e. at the Chukotka Peninsular, in the Kolyma, Omolon, and Anadyr River valleys (see the recent review in Slobodin 1999). Even now we have no assemblages comparable to the Alaskan ones from the chronological viewpoint.

So far, we have one more site in extreme northeastern Siberia-Siberdik in the Kolyma River headwaters (Dikov 1977:213-21; 1979:90-100) (Figure 1, Nr 117). There are several age estimates for the lowermost cultural layer 3, range from around 13,200 BP to around 7900 BP (Kuzmin and Tankersley 1996:580; Kuzmin and Orlova 1998:17; Kuzmin 2000:123), and this fact is well known in spite of skepticism expressed by Goebel and Slobodin (1999:155). Unfortunately, no details about the degree of association between ${ }^{14} \mathrm{C}$-dated charcoal and artifacts from layer 3 were given by Dikov (personal communication to Kuzmin, September 1994). But we cannot simply reject the earliest ${ }^{14} \mathrm{C}$ value of the layer 3 on Siberdik, 13,225 \pm 230 BP (MAG-916) (Lozhkin and Trumpe 1990:178), as was done by Goebel and Slobodin (1999:114) without any discussion. Until there are new site exca- 
vations and dating, this age of the Siberdik still should be taken into account as the tentative evidence of human occupation of the Kolyma headwaters around 13,000 BP. Thus, we can conclude that at least at around 13,000 BP humans already settled the extreme northeastern Siberia, the "forepost" of the peopling of the New World, and the Berelekh, Siberdik, and Ushki might represent the earliest Paleolithic sites there.

Leaving aside faunal occurrences with more or less dubious evidence of human involvement (Old Crow, Trail Creek, and the Lime Hills 1 Caves) and sites with artifactual material but ambiguous stratigraphic resolution (unit B at the Bluefish Caves nos. 1 and 2), it could be said with confidence that the earliest human traces in Alaska are associated with the Nenana and Denali Complex sites, located in the Central Interior Alaska (West 1996). The oldest Nenana assemblages (Components 1 at Owl Ridge, Walker Road, and Dry Creek, Cultural Zones 4 and 3 at Broken Mammoth, Layer 1 at Moose Creek) are dated by ${ }^{14} \mathrm{C}$ from around $11,800-11,100$ to $9000 \mathrm{BP}$. The age of the oldest Denali assemblages is generally slightly younger, around 10,700-9000 BP (Components 2 at Dry Creek and Moose Creek). Recent discoveries revealed more the complex character of the culture development in Beringia with early appearance of microblade industry as evidenced by the lowermost horizons at Swan Point, dated around 11,600 BP.

Assuming Nenana and Denali were separate culture traditions, the Alaskan sites could therefore be regarded as a reflection of two different migration waves from Asia. The oldest seems to be represented by the Nenana assemblages dated from around 12,000-11,000 BP. The second, presumably reflecting the spread of the Dyuktai populations in north-eastward direction, are represented by Denali and dated between 11,000 and 10,000 BP (West 1996).

Apart from these traditions, the northern Paleoindian is represented by the sites with projectile points located in northern and western portions of Alaska. The earliest dates are between around 11,700 and $9700 \mathrm{BP}$ for Mesa, around 10,500 BP for Bedwell, 10,300 BP for Hilltop, and around 11,000 BP for Tuluaq (Bever 2000; Rasic and Gal 2000).

The revision of old data and a search for new data are needed. The achievements along these lines could be only possible through the development of cooperation between Russian and American scholars. There is little doubt that the frozen ground lands of northeastern Asia should contain the traces of the ancestors of the first Americans. The current surge in joint research allows us to see the future of our studies in favorable perspective.

\section{CONCLUSION}

More close collaborative efforts of archaeologists and scientists specializing in ${ }^{14} \mathrm{C}$ dating, Quaternary geology, and geomorphology are necessary for the solution of the problems mentioned above. There is a lot of discordance in publication of ${ }^{14} \mathrm{C}$ dates, especially in terms of laboratory numbers, cultural layer identifications and contexts, and the development of a standard general database is called for. Recently, the Siberian Paleolithic Radiocarbon Database has been compiled (see the website of the Institute of Geology, the Siberian Branch of the Russian Academy of Sciences [www.giscenter.ru]). This paper should be cited as a primary source of the ${ }^{14} \mathrm{C}$ dates for the Paleolithic of Siberia included in the Database.

\section{ACKNOWLEDGMENTS}

We are deeply grateful to Zoia A Abramova, Sergey N Astakhov, Galina V Sinitsyna, Anatoly P Derevianko, Ruslan S Vasil'evskii, Valery T Petrin, Sergey V Markin, Yuri P Kholiushkin, Michael 
V Shun'kov, Yuri V Grichan, Pavel V Volkov, Andrey V Tabarev, Arthur L Kungurov, Nikolay I Drozdov, Nikolay D Ovodov, Elena V Akimova, Nikolay P Makarov, Alexander S Vdovin, German I Medvedev, Michael P Aksenov, Nicholas A Savel'ev, Anatoly G Generalov, Tagir A Abdulov, Irina L Lezhnenko, Victor M Vetrov, Eugene M Ineshin, Nathalie A Berdnikova, Sergey N Perzhakov, Oleg V Zadonin, Liudmila V Lbova, Yuri A Mochanov, Nicholas M Cherosov, Igor I Kirillov, Michael V Konstantinov, Alexander V Konstantinov, Victor K Kolosov, Sergey G Vasil'ev, Oleg K Kuznetsov, Nina A Kononenko, Alexander A Krupianko, Anatoly M Kuznetsov, Valery A Lynsha, Sergey B Slobodin, and many other scholars for friendly discussions and easy access to all kinds of data. The Central European University Research Support Scheme (grant nr 609/1991), the Fulbright Scholar Program (grants nrs 22246 and 21230), the Russian Foundation for Basic Sciences (grant nrs 99-06-80348, 00-06-80376, and 00-06-80410), the Regional Scholar Exchange Program, and the Russian Foundation for Humanities (grant nr 99-01-12010) have supported this research. The first draft of the paper was presented by the senior author at the 2nd Russian Quaternary Conference held in St Petersburg in 1998.

\section{REFERENCES}

Abramova ZA. 1979a. Paleolit Yeniseya: Afontovskaya kul'tura (Paleolithic of the Yenisey: The Afontova culture). Novosibirsk: Nauka Publ. 157 p.

Abramova ZA. 1979b. Paleolit Yeniseya: Kokorevskaya kul'tura (Paleolithic of the Yenisey: The Kokorevo culture). Novosibirsk, Nauka Publ. 200 p.

Abramova ZA. 1979c. O vozraste paleolita Aldana (On the dating of the Paleolithic of Aldan). Sovetskaya arkheologiya 4:5-14.

Abramova ZA. 1989. Paleolit Severnoi Azii (The Paleolithic of Northern Asia). In: Boriskovskiy PI, editor. Paleolit mira. Paleolit Kavkaza i Severnoi Azii. Leningrad: Nauka Publ. p 144-243.

Abramova ZA, Astakhov SN, Vasil'ev SA, Lisitsyn NF, Ermolova NM. 1991. Paleolit Yeniseya (The Paleolithic of the Yenisey). Leningrad: Nauka Publ. 158 p.

Akimova EV. 1998. Istoriya antropologicheskoi nakhodki so stoyanki Listvenka (The story of anthropological finding from the Listvenka site) In: Derevianko AP, editor. Paleoekologiya pleistotsena i kul'tury kamennogo veka Severnoi Azii i sopredel'nykh territoryi. Part 1. Novosibirsk: Institute of Archaeology and Ethnography Press. p 298-300.

Akimova EV, Gorelchenkova OA, Poplevchenko NA. 2000a. Priemy pervichnogo razschepleniya v 19-m kul'turnom sloe stoyanki Listvenka (Lithic technology of the Layer 19 of Listvenka). In: Drozdov NI, editor. Paleogeografiya kamennogo veka. Korrelyatsya prirodnykh sobytyi $i$ arkheologicheskikh kul'tur paleolita Severnoi Azii i sopredel'nykh territoryi. Krasnoyarsk: Krasnoyarsk State Pedagogical University. p $7-$ 9.

Akimova EV, Stasiuk IV, Tomilova EA, Maklaeva YM, Andrenko OV, Gulyaev AA, Zykin VS, Zykina VS, Orlova LA. 2000b. Kompleksnoye izuchenie pozdnepaleoliticheskogo mestonakhozhdeniya Derbina 5 na Krasnoyarskom vodokhranilische (The multidisciplinary study of the Late Paleolithic site of Derbina 5 at the Krasnoyarsk Reservoir). In: Drozdov NI, editor. Paleogeografiya kamennogo veka. Korrelyatsya prirodnykh sobytyi i arkheologicheskikh kul'tur paleolita Severnoi Azii i sopredel'nykh territoryi. Krasnoyarsk: Krasnoyarsk State Pedagogical University. p $10-11$.

Aksenov MP. 1993. Doneoliticheskie mestonakhozhdeniya Verkhnei Leny (Pre-Neolithic sites at the Upper Lena). In: Derevianko AP, editor. Istorichesky opyt osvoeniya vostochnykh raionov Rossii. Part 1. Vladivostok: Far Eastern Branch of the Russian Academy of Sciences. p 67-70.

Aksenov MP. 1996. Doneoliticheskie stoyanki Kachugsko-Verkholenskogo uchastka doliny Verkhnei Leny (Pre-Neolithic sites at the Kachug-Upper Lena portion of the Upper Lena valley). In: Medvedev GI, editor. Arkheologicheskoye nasledie Baikalskoi Sibiri. Part 1. Irkutsk: Center for Cultural Heritage Preservation. $\mathrm{p}$ $12-22$.

Alekseev MN, Golubeva LV, Liskun IG, Sokolovskaya VT. 1986. Klimatostratigrafiya chetvertichnykh otlozhenyi severa Vostochnoi Sibiri (Climatostratigraphy of the Quaternary deposits of the northern Eastern Siberia). Bulleten' Komissii po izucheniyu chetvertichnogo perioda 55:14-26.

Arslanov HA. 1987. Radiouglerod: geokhimiya i geochronologiya (Radiocarbon: geochemistry and geochronology). Leningrad: Leningrad State University Press. 300 p.

Arslanov HA, Svezhentsev YS, Markov YN. 1981. Uluchschennye metody radiouglerodnogo datirovaniya iskopaemykh kostei (Advanced methods of the radiocarbon dating of fossil bones). In: Kurvits YA, editor. Izotopnye $i$ geokhimicheskie metody $v$ biologii, geologii $i$ arkheologii. Tartu: Estonian Academy of Sciences. p 12-15.

Astakhov SN. 1986. Paleolit Tuvy (The Paleolithic of Tuva). Novosibirsk: Nauka Publ. 174 p. 
Astakhov SN, Zubareva GY, Lisitsyn NF, Yamskikh AF. 1993. Paleoliticheskaya stoyanka Shlenka (The Paleolithic site of Shlenka). Rossiiskaya arkheologiya 3: 140-8.

Bazarov DB, Konstantinov MV, Imetkhenov AB, Bazarova LD, Savvinova VV. 1982. Geologiya i kul'tura drevnikh poselenyi Zapadnogo Zabaikalya (The geology and culture of the ancient settlements of the western Transbaikal). Novosibirsk: Nauka Publ. 164 p.

Belousov VM, Ineshin EM, Sulerzhitsky LD, Teten'kin AV. 1997. Nekotorye aspekty sozdaniya dinamicheskoi modeli razvitiya rel'efa $\mathrm{v}$ Mamakanskom geoarkheologicheskom mikroraione (Some aspects of the construction of dynamic model of relief formation in the Mamakan geoarchaeological region). In: Derevianko AP, Molodin VI, editors. Problemy arkheologii, etnografii, antropologii Sibiri i sopredel'nykh territoryi. Vol. 3. Novosibirsk: Institute of Archaeology and Ethnography Press. p 19-23.

Bever MR. 2000. Paleoindian lithic technology and landscape use in Late Pleistocene Alaska: a study of the Mesa Complex. Unpublished PhD dissertation. Dallas: Southern Methodist University.

Bigelow NH. 1991. Analysis of Late Quaternary soils and sediments in the Nenana Valley, central Alaska. Unpublished MA dissertation. Fairbanks: University of Alaska-Fairbanks.

Buerachny EV, Lbova LV. 2000. Osobennosti tekhnologii pazschepleniya industrii Kamenka-A (Peculiarities of the lithic technology from the assemblage of Kamenka-A). In: Drozdov NI, editor. Paleogeografiya kamennogo veka. Korrelyatsya prirodnykh sobytyi $i$ arkheologicheskikh kul'tur paleolita Severnoi Azii i sopredel'nykh territoryi. Krasnoyarsk: Krasnoyarsk State Pedagogical University. p 22-4.

Cherosov NM. 1988. Stoyanki kamennogo veka tsentral'noi chasti Lenskogo Plato (Stone Age sites of the central part of the Lena Plateau). In: Alekseev AN, editor. Arkheologiya Yakutii. Yakutsk: Yakutsk State University. p 54-71.

Derevianko AP, editor. 1997. The Paleolithic of Siberia. Urbana: The University of Illinois Press. 406 p.

Derevianko AP, Agadzhanian AK, Baryshnikov GF, Dergacheva MI, Dupal TA, Malaeva EM, Markin SV, Molodin VI, Nikolaev SV, Orlova LA, Petrin VT, Postnov AV, Ul'ianov VA, Fedeneva IN, Foronova IV, Shun'kov MV. 1998. Arkheologiya, geologiya i paleogeografiya pleistozena i golozena Gornogo Altaya (Archaeology, geology, and paleogeography of the $\mathrm{Pl}$;eistocene and Holocene of the Mountainous Altai). Novosibirsk: Institute of Archaeology and Ethnography Press. 174 p.

Derevianko AP, Bolikhovskaya NS, Markin SV, Sobolev VM. 2000a. Paleogeografiya finala pleistozena srednegornoi zony Severo-Zapadnogo Altaya po dannym izucheniya razrezov peschery Kaminnoi (Paleogeography of the Final Pleistocene in the middle range of northwestern Altai Mountains according to the study of the Kaminnaya Cave sections). In: Markin SV, editor. Problemy rekonstruktsii klimata i prirodnoi sredy golozena i pleistozena Sibiri. Vol. 2. Novosibirsk: Institute of Archaeology and Ethnography Press. p 15461.

Derevianko AP, Drozdov NI, Chekha VP, editors. 1992. Arkheologiya, geologiya $i$ paleogeografiya paleoliticheskikh pamyatnikov yuga Srednei Sibiri (Archaeology, geology and paleogeography of the Paleolithic sites of southern Central Siberia). Krasnoyarsk: Institute of Archaeology and Ethnography Press. 130 p.

Derevianko AP, Zenin VN. 1995a. Paleoliticheskaya stoyanka Shestakovo: osobennosti industrii shestogo kulturnogo sloya (The Paleolithic site of Shestakovo: peculiarities of the industry from the sixth cultural layer). In: Kiriushin YF, editor. Problemy zaschity, izucheniya i okhrany kul'turnogo naslediya na Altaye. Barnaul: Altai State University. p 38-9.

Derevianko AP, Zenin VN. 1995b. Paleolit Selemdzha (The Paleolithic of Selemdga). Novosibirsk: Institute of Archaeology and Ethnography Press. 159 p.

Derevianko AP, Zenin VN, Leshchinsky SV, Mashchenko EN. 2000b. Peculiarities of mammoth accumulation at Shestakovo site in West Siberia. Archaeology, Ethnology, and Anthropology of Eurasia 1(3):4255.

Dikov NN. 1977. Arkheologicheskie pamyatniki Kamchatki, Chukotki i Verkhnei Kolymy (Archaeological sites on Kamchatka, Chukotka, and Upper Kolyma). Moscow: Nauka Publ. 391 p.

Dikov NN. 1979. Drevnie kul'tury Severo-Vostochoi Azii (Ancient cultures of Northeast Asia). Moscow: Nauka Publ. 352 p.

Dikov NN. 1985. The Paleolithic of Northeast Asia and its relations to the Paleolithic of Ameriaround InterNord 17:173-7.

Dikov NN. 1996a. The Ushki sites, Kamchatka Peninsula. In: West FH, editor. American Beginnings: The Prehistory and Palaeoecology of Beringia. Chicago: The University of Chicago Press. p 244-50.

Dikov NN. 1996b. Rannie etapy kamennogo veka: paleolit i mezolit (The early stages of the Stone Age: Paleolithic and Mesolithic) In: Dikov NN, editor. SeveroVostok Rossii ot pervobytnogo vremeni do sovremennosti: novyie vzglady na istoriyu. Magadan: Northeastern Interdisciplinary Research Institute. p 13-22.

Drozdov NI. 1992. Etapy razvitiya kamennogo veka $v$ pleistotsene Srednei Sibiri (Stages of the development of the Stone Age in the Pleistocene Central Siberia). An abstract of doctoral dissertation. Novosibirsk: Institute of Archaeology and Ethnography. 54 p.

Drozdov NI, Artem'ev EV. 1997. Novye dostizheniya v izuchenii paleolita Afontovoi Gory (New achievements in the study of the Paleolithic of Afontova Gora). Moscow: INQUA. 56 p. 
Drozdov NI, Chekha VP, Artem'ev EV, Haesaerts P, Orlova LA. 2000. Chetvertichnaya istoriya i arkheologicheskie pamyatniki Severo-Minusinskoi kotloviny (Quaternary history and archaeological sites of the northern Minusinsk Basin). Krasnoyarsk: Krasnoyarsk State Pedagogical University. 76 p.

Drozdov, NI, Chekha VP, Laukhin SA, Kol'tsova VG, Akimova EV, Ermolaev AV, Leont'ev VP, Vasil'ev SA, Yamskikh AF, Demidenko GA, Artem'ev EV, Vikulov AA, Bokarev AA, Foronova IV, Sidoras SD. 1990. Khronostratigrafiya paleoliticheskikh pamyatnikov Srednei Sibiri (Chronostratigraphy of the Paleolithic sites of Central Siberia). Novosibirsk: Institute of History, Philology, and Philosophy. 185 p.

Drozdov NI, Chlachula J, Chekha VP. 1999. Pleistocene environments and Paleolithic occupation of the northern Minusinsk Basin, southern Krasnoyarsk Region. Anthropozoikum 23:141-56.

Elias SA. 2001. Beringian paleoecology: results from the 1997 workshop. Quaternary Science Reviews 20:713.

Elias SA, Short SK, Birks HH. 1997. Late Wisconsin environments of the Bering Land Bridge. Palaeogeography, Palaeoclimatology, Palaeoecology 136:293-308.

Firsov LV, Panychev VA, Orlova LA. 1985. Katalog radiouglerodnykh dat (The catalogue of radiocarbon dates). Novosibirsk: Institute of Geology and Geophysics. $88 \mathrm{p}$.

Generalov AG. 2000. Geoarkheologichesky ob'ekt Strizhovaya Gora (Geoarchaeological object of the Strizhovaya Gora). Irkutsk: Irkutsk State University Press. $153 \mathrm{p}$

Gening VF, Petrin VT. 1985. Pozdnepaleoliticheskaya epokha yuga Zapadnoi Sibiri (The Late Paleolithic epoch of the southern West Siberia). Novosibirsk: Nauka Publ. 89 p.

Giterman RE. 1985. Istoriya rastitel'nosti Severo-Vostoka SSSR v pliozene i pleistozene (The history of the vegetation of the Northeast USSR in the Pliocene and Pleistocene). Moscow: Nauka Publ. 95 p.

Goebel T. 1993. The Middle to Upper Paleolithic transition in Siberia. Unpublished PhD dissertation. Fairbanks: University of Alaska-Fairbanks.

Goebel T. 1999. Pleistocene human colonization of Siberia and peopling of the Americas: an ecological approach. Evolutionary Anthropology 8(6):208-27.

Goebel T, Aksenov M. 1995. Accelerator radiocarbon dating of the initial Upper Paleolithic in southeast Siberia. Antiquity 69:349-57.

Goebel T, Derevianko AP, Petrin VT. 1993. Dating the Middle-to-Upper Paleolithic transition of Kara-Bom. Current Anthropology 34(4):452-8.

Goebel T, Slobodin SB. 1999. The colonization of western Beringia: technology, ecology, and adaptations. In: Bonnichsen R, Turnmire KL, editors. Ice Age people of North America: environments, origins, and adaptations of the first Americans. Corvallis: Oregon State
University Press. p 156-99.

Goebel T, Waters MR. 2000. New AMS ${ }^{14} \mathrm{C}$ ages for the Tolbaga Upper Paleolithic site, Transbaikal, Siberia. Current Research in the Pleistocene 17:32-4.

Goebel T, Waters MR, Buvit I, Konstantinov MV, Konstantinov AV. 2000. Studenoye-2 and the origins of microblade technologies in the Transbaikal, Siberia. Antiquity 74:567-75.

Henry M. 1984. Absolute chronologies of Late Pleistocene and Early Holocene cultures of Northeast Asia. Arctic Anthropology 21(1):1-68.

Ineshin EM. 1993. Deyatelnostnyi podkhod k izucheniiu planigrafii arkheologicheskogo pamytnika Bolshoi Yakor (Behavioral approach to the study of the spatial structure of the archaeological site of Bol'shoi Yakor). In: Derevianko AP, editor. Istorichesky opyt osvoeniya vostochnykh raionov Rossii. Part 1. Vladivostok: Far Eastern Branch of the Russian Academy of Sciences. p. 67-74.

Kaplina TN, Giterman RE. 1983. Molotkovsky Kamen oporny razrez otlozhenyi pozdnego pleistozena Kolymskoi nizmennosti (The Molotkovsky Kamen an key section of the Late Pleistocene of the Kolyma Lowland). Izvestiya AN SSSR. Seriya geologicheskaya 6:79-83.

Kaplina TN, Lozhkin AV. 1982. Vozrast "ledovogo kompleksa" Primorskikh nizmennostei Yakutii (The age of the "Ice Complex" of the coastal Yakutain lowlands). Izvestiya AN SSSR. Seriya geologicheskaya 2: 84-95.

Kashin VA. 1983. Istoriya issledovaniya i rezul'taty izucheniya paleolita Yakutii (History of research and results of the studies of the Paleolithic of Yakitia). In: Vasil'evsky RS, editor. Paleolit Sibiri. Novosibirsk: Nauka Publ. p 111-23.

Kind NV. 1974. Geokhronologiya pozdnego antropogena po izotopnym dannym (Geochronology of the Late Anthropogene according to isotopic data). Moscow: Nauka Publ. 255 p.

Kind NV, Sulerzhitsky LD, Vinogradova SN. 1976. Radiouglerodnye datirovki GIN AN SSSR. Soobshchenie 8 (Radiocarbon dates of GIN AN SSSR, report No. 8). Bulleten' Komissii po izucheniyu chetvertichnogo perioda 46:169-85.

Kirillov II, Cherenshchikov OY. 1996. Netraditsionnye izdeliya iz kamnya s mnogosloinoi stoyanki Sukhotino 4 (Non-traditional lithic artifacts from the multicomponent Paleolithic site of Sukhotino 4). In: Lezhnenko IL, editor. Arkheologiya, paleoekologiya $i$ etnografiya Sibiri i Dal'nego Vostoka. Part 1. Irkutsk: Irkutsk State University. p 125-30.

Kirillov II, Kasparov AK. 1990. Arkheologiya Zabaikal'a: problemy i perspektivy (epokha paleolita) (Archaeology of the Transbaikal: problems and perspectives of the Paleolithic period). In: Derevianko AP, editor. Khronostratifraphiya paleolita Severnoi, Centralnoi i Vostochnoi Azii i Ameriki. Novosibirsk: 
Institute of History, Philology, and Philosophy. p 1948.

Klement'ev AM. 2000. Krupnye mlekopitayuschie paleolita Zabaikal'ya (Large mammals from the Paleolithic of Transbaikal). In: Drozdov NI, editor. Paleogeografiya kamennogo veka. Korrelyatsya prirodnykh sobytyi i arkheologicheskikh kul'tur paleolita Severnoi Azii i sopredel'nykh territoryi. Krasnoyarsk: Krasnoyarsk State Pedagogical University. p 68-70.

Konstantinov MV. 1994. Drevnie pamyatniki kamennogo veka Baikalskoi Azii (The Stone Age archaeological sites of the Baikal Asia). Chita: Chita State Teacher Training College Press. $180 \mathrm{p}$.

Kostiukevich VV, Degtiareva GP, Ivanov IE, Nesterenko SA. 1977. Radiouglerodnye daty laboratorii Instituta merzlotovedeniya SO AN SSSR (Radiocarbon dates of the laboratory, Permafrost Research Institute SO AN SSSR. Bulleten' Komissii po izucheniyu chetvertichnogo perioda 47:145-52.

Kostiukevich VV, Dneprovskaya OA, Ivanov IE. 1984 Radiouglerodnye datirovki laboratorii Instituta merzlotovedeniya (Radiocarbon dates of the Laboratory of Permafrost Research Institute). Bulleten' Komissii po izucheniyu chetvertichnogo perioda 53:172-4.

Kostiukevich VV, Ivanov IE, Nesterenko SA. 1980. Spisok radiouglerodnykh dat laboratorii geokhimii Instituta merzlotovedeniya SO AN SSSR (A roster of radiocarbon dates of the geochemistry laboratory, Permafrost Research Institute SO AN SSSR). Bulleten' Komissii po izucheniyu chetvertichnogo perioda 50:193-6.

Kozhevnikov YP, Zheleznov-Chukotsky NK. 1995. Berigniya: istoriya i evolutsiya (Beringia: history and evolution). Moscow: Nauka Publ. 383 p.

Krenke NA, Sulerzhitsky LD. 1992. Arkheologiya i realnaya tochnost radiouglerodnogo metoda (Archaeology and the real accuracy of radiocarbon method). In: Chichagova OA, Punning J-M, Kind NV, editors. Geokhronologiya chetvertichnogo perioda. Moscow: Nauka Publ. p 169-74.

Krupianko AA, Tabarev AV. 2001. Arkheologicheskie kompleksy epokhi kamnya $v$ Vostochnom Primorye (Archaeological complexes of the Stone Age in eastern Maritime Province). Novosibirsk: Siberian University Publ. 104 p.

Kuzmin YV. 1994. Prehistoric colonization of Northeastern Siberia and migration to America: radiocarbon evidence. Radiocarbon 36(3):367-376.

Kuzmin YV. 1996. Palaeoecology of the Palaeolithic of the Russian Far East. In: West FH, editor. American beginnings: the prehistory and palaeoecology of Beringia. Chicago \& London: University of Chicago Press. p 136-46.

Kuzmin YV. 2000. Geoarchaeology of the Lower, Middle, and early Upper Palaeolithic of Siberia: a review of current evidence. The Review of Archaeology 21(1): $32-40$.
Kuzmin YV, Jull AJT, Orlova LA, Sulerzhitsky LD. 1998a. ${ }^{14} \mathrm{C}$ chronology of the Stone Age cultures, Russian Far East. Radiocarbon 40(2):675-86.

Kuzmin YV, Orlova LA. 1998. Radiocarbon chronology of the Siberian Paleolithic. Journal of World Prehistory 12(1):1-53.

Kuzmin YV, Orlova LA, Sulerzhitsky LD, Jull AJT. 1994. Radiocarbon dating of the Stone and Bronze Age sites in Primorye (Russian Far East). Radiocarbon 36(3):359-66.

Kuzmin YV, Tankersley KB. 1996. The colonization of Eastern Siberia: an evaluation of the Paleolithic age radiocarbon dates. Journal of Archaeological Science 23(4):577-85.

Kuzmin YV, Vasilevsky AA, O’Malley JM, Jull AJT. 1998b. The age and environment of the Paleolithic occupation of Sakhalin Island, the Russian Far East. Current Research in the Pleistocene 15:134-6.

Kuz'mina I, Sinitsyna G. 1995. Importance of faunistic remains for the chronology of multilayered Biryusa site in the Middle Yenisei area. In: Baryshnikov G, Kuzmina I, Saunders J, editors. First International Mammoth symposium. St Petersburg: Russian Academy of Sciences. p 682-3.

Kuznetsov AM. 1992. Pozdny paleolit Primorya (The Late Paleolithic of the Maritime Territory). Vladivostok: Far Eastern State University Press. 240 p.

Larichev V, Kholiushkin Y, Laricheva I. 1988. The Upper Paleolithic of Northern Asia: achievements, problems and perspectives (I) - western Siberia. Journal of World Prehistory 2(4):359-96.

Larichev V, Kholiushkin Y, Laricheva I. 1990. The Upper Paleolithic of Northern Asia: achievements, problems and perspectives (II) - central and eastern Siberia. Journal of World Prehistory 4(3):347-385.

Larichev V, Kholiushkin Y, Laricheva I. 1992. The Upper Paleolithic of northern Asia: achievements, problems and perspectives (III) - northeastern Siberia and Russian Far East. Journal of World Prehistory 6(4):44176.

Laukhin, SA, Drozdov NI, Panychev VA, Velichko SV. 1989. The date of the last glaciation in northern East Chukotka. International Geological Review 31:52731.

Lbova LV. 1996a. Paleoliticheskoe poselenie Varvarina Gora (The Paleolithic settlement of Varvarina Gora). In: Konstantinov MV, editor. Novye paleoliticheskie pamyatniki Zabaikalya. Chita: Chita State Teacher Trainers College. p 11-23.

Lbova LV. 1996b. Paleoliticheskoe mestonakhozhdenie Kamenka (The Paleolithic locality of Kamenka). In: Konstantinov MV, editor. Novye paleoliticheskie pamyatniki Zabaikalya. Chita: Chita State Teacher Trainers College. p 24-47.

Lbova LV, Bazarov BA, Buerachny EV. 1997. MukhorTala: perspektivy izucheniya finalnogo paleolita $\mathrm{v}$ Buryatii (Mukhor-Tala: perspectives for the study of 
the Final Paleolithic in Buriatia). In: Vetrov VM, editor. Dulovskie chteniya - 1997. Irkutsk: Irkutsk State University. p 19-23.

Lisitsyn NF. 2000. Pozdny paleolit Chulymo-Eniseiskogo mezhdurechiya (The Late Paleolithic of Chulym-Yenisey region). St Petersburg: Petersburg Oriental Studies Press. $232 \mathrm{p}$.

Lisitsyn NF, Svezhentsev YS. 1997. Radiouglerodnaya khronologiya verkhnego paleolita Severnoi Azii (The radiocarbon chronology of the Upper Paleolithic of Northern Asia). In: Sinitsyn AA, Praslov ND, editors. Radiouglerodnaya khronologiya paleolita Vostochnoi Evropy i Severnoi Azii: problemy i perspektivy. St Petersburg: Institute of the History of Material Culture. p 67-108.

Longin R. 1971. New method of collagen extraction for radiocarbon dating. Nature 230:241-2.

Lozhkin, AV, Trumpe MA. 1990. Sistematizatsiya radiouglerodnykh datirovok arhkeologicheskikh pamyatnikov Magadanskoi oblasti (Systematization of radiocarbon dates of the archaeological sites on the Magadan District). In: Dikov NN, editor. Drevnie pamyatniki Severa Dalnego Vostoka. Magadan: Northeastern Interdisciplinary Research Institute. $\mathrm{p}$ 176-9.

MacPhee RDE, Tikhonov AN, Mol D, de Marliave C, van der Plicht J, Greenwood AD, Fleming C, Agenbroad L. 2002. Radiocarbon chronologies and extinction dynamics of the Late Quaternary mammalian megafauna of the Taimyr Peninsula, Russian Federation. Journal of Archaeological Science 29:1017-42.

Medvedev GI, Berdnikov AM, Fedorenko AB. 1991. Nekotorye voprosy izucheniya dokeramicheskikh mestonakhozhdenii Angaro-Osinskogo raiona (Some aspects of the study of the pre-ceramic localities in the Angara-Osa area). In: Medvedev GI, editor. Paleoetnologicheskie issledovaniya na yuge Srednei Sibiri. Irkutsk: Irkutsk State University. p 5-14.

Medvedev G, Cauwe N, Vorob'eva G, Coupe D, Claes L, Lipnina E, Modrie S, Mukharramov S, Osadchy S, Pettitte P, Rebrikov P, Rogovsky E, Sitlivyi V, Sulerzhitsky L, Khenzykhenova D. 1996. Paleoliticheskoye mestonakhozhdenie Malta (The Malta Paleolithic locality). Irkutsk: ARCOM Press. 31 p.

Medvedev GI, Savel'ev NA, Svinin VV, editors. 1990. Stratigrafiya, paleogeografiya i arkheologiya yuga Srednei Sibiri (Stratigraphy, paleogeography, and archaeology of the southern Central Siberia). Irkutsk: Irkutsk State University Press. 165 p.

Meshcherin MN. 1996. Kharakteristika industryi pozdnekarginskogo - rannesartanskogo vremeni Zapadnogo Zabaikal'ya (Characterization of the Late Karginsky - Early Sartan age industries from the western Transbaikal). In: Kononenko NA, editor. Pozdny paleolit - ranny neolit Vostochnoi Azii i Severnoi Ameriki. Vladivostok: Dalpress Publ. p 184-6.

Mochanov YA. 1977. Drevneishie etapy zaseleniya che- lovekom Severo-Vostochoi Azii (The most ancient stages of human settling of Northeast Asia). Novosibirsk: Nauka Publ. 264 p.

Mochanov YA. 1984. Paleolithic finds in Siberia (resume of studies). In: Kontrimavichus VI, editor. Beringia in Cenozoic Era. New Delhi: Amerind Publ. p 694-724.

Muratov VM, Ovodov ND, Panychev VA, Safarova SA. 1982. Obschaya kharakteristika paleoliticheskoi stoyanki Malaya Syia v Khakasii (A general view of the Paleolithic site of Malaia Syia in Khakasiya). In: Konopatsky AK, Khudiakov YS, editors. Arkheologiya Severnoi Azii. Novosibirsk: Nauka Publ. p 33-48.

Nokhrina TI, Dergacheva MI, Petrin VT, Nikolaev SV. 2000. Peschernyie stoyanki Biika v doline Srednei Katuni (The Biika Cave sites at the Middle Katun' valley). In: Kiriushin YF, Tishkin AA, editors. Okhrana $i$ izuchenie kul'turnogo naslediya Altaya. Volume 11. Barnaul: Altai State University Press. p 77-9.

Okladnikov AP. 1981. Paleolit Tsentralnoi Azii. Moiltyn Am (Paleolithic of Central Asia: Moil'tyn Am). Novosibirsk: Nauka Publ. 461 p.

Okladnikov AP, Grigorenko BG, Alexeeva EV, Volkov IA. 1971. Stoyanka verkhnepaleoliticheskogo cheloveka Volchya Griva (A site of Upper Paleolithic man at Volchia Griva). In: Okladnikov AP, editor. Materialy Dal'nevostochnoi arkheologicheskoi ekspeditsii. Part 2. Novosibirsk: Institute of History, Philology, and Philosophy. p 87-131.

Okladnikov AP, Kirillov II. 1980. Iugo-vostochnoe Zabaikalie v epokhu kamnya i rannei bronzy (The southeastern Transbaikal area in the Stone and Early Bronze Epoch). Novosibirsk: Nauka Publ. 177 p.

Orlova LA. 1979. Radiouglerodny vozrast iskopaemykh ostatkov mamonta na territorii SSSR (Radiocarbon age of the fossil mammoth remains on the USSR territory). Izvestiya Sibirskogo Otdeleniya AN SSSR. Seriya obschestvennykh nauk 16(2):89-97.

Orlova LA. 1995. Radiouglerodnoye datirovanie arkheologicheskikh pamyatnikov Sibiri i Dalnego Vostoka. Soobschenie 1 (Radiocarbon dating of archaeological sites from Siberia and the Russian Far East. Report 1). In: Derevianko AP, Kholushkin YP, editors. Metody estestvennykh nauk $v$ arheologicheskikh rekonstruktsiyakh. Novosibirsk: Institute of Archaeology and Ethnography Press. p 207-32.

Orlova LA, Kuzmin YV, Volkova VS, Zolnikov ID. 2000b. Mamont (Mammuthus primigenius Blum.) i drevny chelovek v Sibiri: sopryazhenny analiz arealov populyatsyi na osnove radiouglerodnykh dannykh (Mammoth (Mammuthus primigenius Blum.) and prehistoric humans in Siberia: conjunctive spatial analysis of distributions based on the radiocarbon evidence). In: Markin SV, editor. Problemy rekonstruktsii klimata i prirodnoi sredy golozena i pleistozena Sibiri. Volume 2. Novosibirsk: Institute of Archaeology and Ethnography Press. p 383-412. 
Orlova LA, Leschinsky SV, Zenin VN, Borisov MA. 2000a. Radiouglerodnye i stratigraficheskie issledovaniya mestonakhozhdeniya Volchya Griva v 2000 godu (Radiocarbon and stratigraphical studies of the Volchya Griva locality in 2000). In: Derevianko AP, Molodin VI, editors. Problemy arkheologii, etnografii, antropologii Sibiri i sopredel'nykh territoryi. Vol. 6. Novosibirsk: Institute of Archaeology and Ethnography Press. p 188-91.

Ovodov ND. 1975. Fauna paleoliticheskikh stoyanok Sibiri i problema khronologicheskikh i paleolandschaftnykh tolkovanyi (Fauna of the Paleolithic sites of $\mathrm{Si}$ beria and problem of their chronological and environmental interpretations). In: Derevianko AP, editor. Sootnosheniye drevnikh kul'tur Sibiri s kul'turami sopredel'nykh territoryi. Novosibirsk: Institute of History, Philology, and Philosophy. p 35-50.

Ovodov ND, Muratov VM, Panychev VA, Orlova LA. 1992. Novye dannye po geologii i teriofaune grota Proskuryakova (New data on the geology and mammalian fauna of the Proskuriakov rockshelter). In: Konstantinov MV, Rudenko YT, Zarubin, VG, editors. Petr Alexeevich Kropotkin. Chita: Chita State Teacher Trainers College. p 43-5.

Ovodov ND, Tomilova EA. 1998. Neandertal'tsy na Enisee (The Neanderthals at the Yenisey). In: Derevianko AP, editor. Paleoekologiya pleistozena i kul'tury kamennogo veka Severnoi Azii i sopredel'nykh territoryi. Part 1. Novosibirsk: Institute of Archaeology and Ethnography Press. p 379-85.

Petrin VT. 1986. Paleoliticheskie pamyatniki ZapadnoSibirskoi Ravniny (The Paleolithic sites of the West Siberian Plain). Novosibirsk: Nauka Publ. 142 p.

Péwé TL. 1975. Quaternary Geology of Alaska. Geological Survey Professional Papers 835. Washington: US Geological Survey.

Praslov ND, Sulerzhitsky LD. 1997. De nouvelles données chronologiques pour le Paléolithique de Kostenki-sur-Don. Préhistoire Européenne 11:133-43.

Rasic J, Gal R. 2000. An early lithic assemblage from the Tuluaq site, Northwest Alaska. Current Research at the Pleistocene 17:66-8.

Savvinova GM, Mochanov YA, Fedoseeva SA. 1996. Pollen records from archaeological sites in the Aldansky Region, Sakha Republic. In: West FH, editor. American beginnings: the prehistory and palaeoecology of Beringia. Chicago: The University of Chicago Press. p 97-107.

Shmygun PE, Filippov AK. 1982. Nizhny komponent Kurlinskikh stoyanok (The lower component of the Kurla sites). In: Generalov AG, editor. Material'naya kul'tura i drevnee naselenie Vostochnoi Sibiri. Irkutsk: Irkutsk State University Press. p 15-24.

Shofman IL, Kind NV, Pakhomov MM, Prokopchuk BI, Vinogradova SN, Sulerzhitsky LD, Forova VS. 1977. Novye dannye o vozraste nizkikh terras $v$ basseine reki Vilyi (New data about the age of the lower ter- races in the Vilui River valley). Bulleten' Komissii po izucheniyu chetvertichnogo perioda 47:100-7.

Slobodin SB. 1999. Northeast Asia in the Late Pleistocene and Early Holocene. World Archaeology 30: 484-502.

Stafford TW Jr, Hare PE, Currie L, Jull AJT, Donahue D. 1991. Accuracy of North American human skeleton ages. Quaternary Research 34(1):111-20.

Starikov EV, Zhidovlenko VA, Gorozhankina SM. 1991. Radiouglerodnye daty Instituta lesa i drevesiny. Soobshchenie 5 (Radiocarbon dates of the Institute of wood and timber. Information no. 5). Bulleten' Komissii po izucheniyu chetvertichnogo perioda 60:143-4.

Sulerzhitsky LD. 1997. Cherty radiouglerodnoi khronologii mamontov Sibiri i severa Vostochnoi Evropy kak substrata dlya rasseleniya cheloveka (Patterns of the radiocarbon chronology of mammoths in Siberia and northern Eastern Europe as sub-stratum for human dispersal). In: Velichko AA, Soffer O, editors. Chelovek zaselyaet planetu Zemlya. Moscow: Institute of Geography. p 184-202.

Sulerzhitsky LD, Vinogradova SN, Ryabinin AL, Man'ko RV. 1987. Radiouglerodnye daty Geologicheskogo Instituta AN SSSR. Soobschenie 8 (Radiocarbon dates of the Geological Institute AN SSSR. Report 8). Bulleten' Komissii po izucheniyu chetvertichnogo perioda 56:149-54.

Svezhentsev YS, Lisitsyn NF, Vasil'ev SA. 1992. Radiouglerodnaya khronologiya Eniseiskogo paleolita (Radiocarbon chronology of the Paleolithic of Yenisey). In: Derevianko AP, editor. Khronostratigraphiya paleolita Severnoi, Centralnoi $i$ Vostochnoi Azii $i$ Ameriki. Novosibirsk: Institute of History, Philology, and Philosophy. p 57-64.

Tashak VI. 1996. Paleolit i mezolit iuga Buryatii (The Paleolithic and Mesolithic in the southern part of Buriatia). Abstract of the candidate of science dissertation. Novosibirsk: Institute of Archaeology and Ethnography. $18 \mathrm{p}$.

Taylor RE. 1997. Radiocarbon dating. In: Taylor RE, Aitken MJ, editors. Chronometric dating in archaeology. New York \& London: Plenum Press. p 65-96.

Ten Brink NW. 1984. North Alaska Range Project. Final report on 1978-1982 Geo-archaeological studies. Allendale: Grand Valley State College.

Tseitlin SM. 1979. Geologiya paleolita Severnoi Azii (Geology of Paleolithic of Northern Asia). Moscow: Nauka Publ. 236 p.

Tseitlin SM. 1983. Tomskaya stoyanka (The site of Tomskaya). Bulleten' Komissii po izucheniyu chetvertichnogo perioda 52:181-2.

Vasil'chuk YK, Vasil'chuk AC, Long A, Jull AJT, Donahue DJ. 2000. AMS dating mammoth bones: Comparison with conventional dating. Radiocarbon 42(2):281-4.

Vasil'ev SA. 1993. The Upper Paleolithic of Northern Asia. Current Anthropology 34(1):82-92. 
Vasil'ev SA. 1996. Pozdny paleolit Verkhnego Eniseya (The Late Paleolithic of the Upper Yenisey). St Petersburg: Petersburg Oriental Studies Press. 224 p.

Vetrov VM. 1995. Stone Age cultures of Upper Vitim. In: Kajiwara H, editor. The origin of ceramics in the Far East. Sendai: Tohoku Fukushi University Press. p 315.

Vorob'eva GA. 1991. Paleogeograficheskie usloviya osadkonakopleniya i otlozheniya mnogosloinoi stoyanki kamennogo veka Sosnovy Bor (Paleogeographical conditions of sedimentation and deposits of the multicomponent Stone Age site of Sosnovy Bor). In: Medvedev GI, editor. Paleoetnologicheskie issledovaniya na yuge Srednei Sibiri. Irkutsk: Irkutsk State Uiversity Press. p 15-25.

Vorob'eva GA, Generalov AG, Zagrafsky SI. 1998. Paleoliticheskie ob'ekty 30-go tysyacheletiya na yuge Srednei Sibiri (Archaeological sites dated to around 30,000 BP in the southern Central Siberia). In: Derevianko AP, editor. Paleoekologiya pleistozena $i$ kul'tury kamennogo veka Severnoi Azii i sopredel'nykh territoryi. Part 2. Novosibirsk: Institute of Archaeology and Ethnography Press. p 46-54.

West FH, editor. 1996. American beginnings. the prehistory and palaeoecology of Beringia. Chicago: The University of Chicago Press. $576 \mathrm{p}$.

Yi S, Clark G. 1985. The "Dyuktai culture" and New World origins. Current Anthropology 26(1):1-20.

Zadonin OV. 1996. Paleoliticheskoe mestonakhozhdenie Alexeevsk I (Paleolithic locality of Alexeevsk I). In: Medvedev GI, editor. Arkheologicheskoye nasledie Baikalskoi Sibiri. Part 1. Irkutsk: Center for Cultural
Heritage Preservation. p 23-7.

Zenin VN, Leshchinsky SV, Fedeneva IN, Orlova LA, Borisov MA. 2000a. Novye paleoliticheskie kompleksy Tom'-Eniseiskogo mezhdurechya (New Paleolithic assemblages from the Tom'-Yenisey watershed). In: Drozdov NI, editor. Paleogeografiya kamennogo veka. Korrelyatsya prirodnykh sobytyi $i$ arkheologicheskikh kul'tur paleolita Severnoi Azii i sopredel'nykh territoryi. Krasnoyarsk: Krasnoyarsk State Pedagogical University. p 56-8.

Zenin VN, van der Plicht J, Orlova LA, Kuzmin YV, Brantingham PJ. 2000b. Geoarchaeology of the Shestakovo Upper Paleolithic site, Western Siberia: human-mammoth interactions during the Last Glacial Maximum. Current Research in the Pleistocene 17: $142-4$.

Zenin VN, Orlova LA, van der Plicht J. 2000c. Radiouglerodnoye datirovanie stoyanki Shestakovo (Radiocarbon dating of the site of Shestakovo). In: Drozdov NI, editor. Paleogeografiya kamennogo veka. Korrelyatsya prirodnykh sobytyi $i$ arkheologicheskikh kul'tur paleolita Severnoi Azii i sopredel'nykh territoryi. Krasnoyarsk: Krasnoyarsk State Pedagogical University. p 61-2.

Zenin VN, van der Plicht J, Orlova LA, Kuzmin YV. 2000d. AMS ${ }^{14} \mathrm{C}$ chronology of woolly mammoth (Mammuthus primigenius Blum.) remains from the Shestakovo Upper Paleolithic site, Western Siberia: timing of human-mammoth interaction. Nuclear Instruments and Methods in Physics Research B 172: $745-50$. 


\section{APPENDIX}

Table 1 Results from the updated ${ }^{14} \mathrm{C}$ Database of the Siberian Paleolithic

\begin{tabular}{|c|c|c|c|c|c|c|c|}
\hline $\begin{array}{l}\text { Site } \\
\mathrm{nr}\end{array}$ & $\begin{array}{l}\text { Lat. } \\
\mathrm{N}\end{array}$ & $\begin{array}{l}\text { Long. } \\
\mathrm{E}\end{array}$ & $\begin{array}{l}\text { Site name, } \\
\text { sample position }\end{array}$ & Material & Lab code & ${ }^{14} \mathrm{C}$ date $\mathrm{BP}$ & Reference \\
\hline \multicolumn{8}{|c|}{ Mousterian assemblages } \\
\hline \multirow[t]{4}{*}{1} & 51.40 & 84.67 & Denisova Cave, Layer 21 & Humic acids & SOAN-2499 & $39,390 \pm 1310$ & Derevianko et al. 1998 \\
\hline & & & Denisova Cave, Layer 21 & Charcoal & GX-17599 & $35,140 \pm 670^{*}$ & Kuzmin \& Orlova 1998 \\
\hline & & & Denisova Cave, Layer 21 & Humic acids & SOAN-2488 & $>34,700$ & Derevianko et al. 1998 \\
\hline & & & $\begin{array}{l}\text { Denisova Cave, } \\
\text { Entrance, Layer } 9\end{array}$ & Charcoal & GX-17602 & $46,000 \pm 2,300 *$ & Kuzmin \& Orlova 1998 \\
\hline \multirow[t]{7}{*}{2} & 51.67 & 84.33 & $\begin{array}{l}\text { Okladnikov Cave, } \\
\text { Layer } 3\end{array}$ & Bone & RIDDL-722 & $\begin{array}{l}43,300 \pm \\
1,300 /-1,500 *\end{array}$ & Derevianko et al. 1998 \\
\hline & & & $\begin{array}{l}\text { Okladnikov Cave, } \\
\text { Layer } 3\end{array}$ & Bone & RIDDL-720 & $\begin{array}{l}40,700 \pm \\
1,100 *\end{array}$ & Derevianko et al. 1998 \\
\hline & & & $\begin{array}{l}\text { Okladnikov Cave, } \\
\text { Layer } 3\end{array}$ & Bone & RIDDL-721 & $32,400 \pm 500^{*}$ & Derevianko et al. 1998 \\
\hline & & & $\begin{array}{l}\text { Okladnikov Cave, } \\
\text { Layer } 2\end{array}$ & Bone & RIDDL-719 & $37,750 \pm 750 *$ & Derevianko et al. 1998 \\
\hline & & & $\begin{array}{l}\text { Okladnikov Cave, } \\
\text { Layer } 1\end{array}$ & Bone & RIDDL-718 & $33,500 \pm 700^{*}$ & Derevianko et al. 1998 \\
\hline & & & $\begin{array}{l}\text { Okladnikov Cave, } \\
\text { Layer } 3\end{array}$ & Bone & SOAN-2459 & $28,470 \pm 1,250$ & Derevianko et al. 1998 \\
\hline & & & $\begin{array}{l}\text { Okladnikov Cave, } \\
\text { Layer } 3\end{array}$ & Bone & SOAN-2458 & $>16,210$ & Derevianko et al. 1998 \\
\hline \multirow[t]{2}{*}{3} & 51.17 & 83.02 & $\begin{array}{l}\text { Strashnaya Cave, depth } 4 \\
\text { to } 3 \mathrm{~m} \text { (Layer } 3 / 3)\end{array}$ & Bone & SOAN-785 & $>25,000$ & Orlova 1995 \\
\hline & & & Strashnaya Cave & Bone & SOAN-3219 & $31,510 \pm 2,615$ & Kuzmin \& Orlova 1998 \\
\hline \multirow[t]{2}{*}{4} & 51.17 & 86.20 & Biika 1, Layer 5 & Bone & Bln-4981 & $37,000 \pm 1,000$ & Nokhrina et al. 2000 \\
\hline & & & Biika 1, Layer 5 & Bone & $B \ln -4980$ & $23,480 \pm 300$ & Nokhrina et al. 2000 \\
\hline \multirow[t]{2}{*}{5} & 50.72 & 85.57 & Kara-Bom, Stratum M1 & Bone & AA-8894 & $>44,000^{*}$ & Derevianko et al. 1998 \\
\hline & & & Kara-Bom, Stratum M1 & Bone & AA- 8873 & $>42,000^{*}$ & Derevianko et al. 1998 \\
\hline 6 & 54.58 & 86.37 & Mokhovo 2 & Bone & SOAN-2861 & $30,330 \pm 445$ & Orlova 1995 \\
\hline \multirow[t]{3}{*}{7} & 56.82 & 86.23 & Aryshevskoe 1, Stratum 2 & Humic acids & SOAN-4178 & $>40,000$ & Zenin et al. 2000a \\
\hline & & & Aryshevskoe 1, Stratum 2 & Humic acids & SOAN-4179 & $>40,000$ & Zenin et al. 2000a \\
\hline & & & Aryshevskoe 1, Stratum 6 & Charcoal & SOAN-4180 & $33,630 \pm 995$ & Zenin et al. 2000a \\
\hline 8 & 56.87 & 86.17 & $\begin{array}{l}\text { Voronino-Yaya, above } \\
\text { cultural layer }\end{array}$ & Bone & SOAN-3837 & $28,450 \pm 850$ & Zenin et al. 2000a \\
\hline 9 & 54.13 & 90.95 & Dvuglazka Cave, Layer 7 & Bone & LE-4811 & $27,200 \pm 800$ & $\begin{array}{l}\text { Lisitsyn \& Svezhentsev } \\
1997\end{array}$ \\
\hline \multirow[t]{4}{*}{10} & 54.45 & 89.47 & $\begin{array}{l}\text { Proskuriakov Rockshel- } \\
\text { ter }\end{array}$ & Bone & SOAN-1519 & $40,770 \pm 1,075$ & Ovodov et al. 1992 \\
\hline & & & $\begin{array}{l}\text { Proskuriakov Rockshel- } \\
\text { ter }\end{array}$ & Bone & SOAN-1517 & $40,690 \pm 1,150$ & Ovodov et al. 1992 \\
\hline & & & $\begin{array}{l}\text { Proskuriakov Rockshel- } \\
\text { ter }\end{array}$ & Bone & SOAN-1518 & $40,595 \pm 875$ & Ovodov et al. 1992 \\
\hline & & & $\begin{array}{l}\text { Proskuriakov Rockshel- } \\
\text { ter }\end{array}$ & Bone & SOAN-848 & $>40,000$ & Ovodov 1975 \\
\hline \multirow[t]{2}{*}{11} & 55.17 & 91.58 & Kurtak 4, Stratum 17 & Bone & LE-3638 & $32,280 \pm 280$ & Svezhentsev et al. 1992 \\
\hline & & & Kurtak 4, Stratum 17 & Charcoal & LE-3352 & $31,650 \pm 520$ & Svezhentsev et al. 1992 \\
\hline \multirow[t]{5}{*}{12} & 55.22 & 91.65 & Ust'-Izhul' & Bone & SOAN-3334 & $>45,000$ & $\begin{array}{l}\text { Ovodov \& Tomilova } \\
1998\end{array}$ \\
\hline & & & Ust'-Izhul' & Charcoal & $\begin{array}{l}\text { AECV- } \\
2034 C\end{array}$ & $>42,190$ & Drozdov et al. 1999 \\
\hline & & & Ust'-Izhul' & Bone & $\begin{array}{l}\text { AECV- } \\
1939 C\end{array}$ & $>42,100$ & Drozdov et al. 1999 \\
\hline & & & Ust'-Izhul' & Charcoal & $\begin{array}{l}\text { AECV- } \\
2032 C\end{array}$ & $>41,810$ & Drozdov et al. 1999 \\
\hline & & & Ust'-Izhul' & Charcoal & $\begin{array}{l}\text { AECV- } \\
2033 \mathrm{C}\end{array}$ & $>40,050$ & Drozdov et al. 1999 \\
\hline 13 & 51.25 & 112.25 & Arta 2, up from Layer 5 & Charcoal & LE-2967 & $37,360 \pm 2,000$ & $\begin{array}{l}\text { Kirillov \& Kasparov } \\
1990\end{array}$ \\
\hline \multicolumn{8}{|c|}{ Upper Paleolithic Assemblages } \\
\hline \multicolumn{8}{|c|}{ Western Siberia and Altai Mountanis } \\
\hline 14 & 56.32 & 66.37 & Shikaevka & Bone & SOAN-2211 & $18,050 \pm 95$ & This paper \\
\hline
\end{tabular}

*AMS dates are shown by asterisks; other dates are conventional 
Table 1 Results from the updated ${ }^{14} \mathrm{C}$ Database of the Siberian Paleolithic

\begin{tabular}{|c|c|c|c|c|c|c|c|}
\hline $\begin{array}{l}\text { Site } \\
\text { nr }\end{array}$ & $\begin{array}{l}\text { Lat. } \\
\mathrm{N}\end{array}$ & $\begin{array}{l}\text { Long. } \\
\text { E }\end{array}$ & $\begin{array}{l}\text { Site name, } \\
\text { sample position }\end{array}$ & Material & Lab code & ${ }^{14} \mathrm{C}$ date $\mathrm{BP}$ & Reference \\
\hline 15 & 55.50 & 73.43 & $\begin{array}{l}\text { Chernoozierye } 2 \text {, } \\
\text { Layers } 3 \text { to } 2\end{array}$ & Charcoal & GIN-122 & $14,500 \pm 50$ & Gening \& Petrin 1985 \\
\hline \multirow[t]{6}{*}{16} & \multirow[t]{6}{*}{54.65} & \multirow[t]{6}{*}{80.25} & Volchiya Griva & Bone & SOAN-111 & $14,450 \pm 110$ & Firsov et al. 1985 \\
\hline & & & Volchiya Griva & Bone & SOAN-78 & $14,200 \pm 520$ & Okladnikov et al. 1971 \\
\hline & & & Volchiya Griva & Bone & SOAN-111 & $13,600 \pm 230$ & $\begin{array}{l}\text { Lisitsyn \& Svezhentsev } \\
1997\end{array}$ \\
\hline & & & Volchiya Griva & Bone & $\begin{array}{l}\text { SOAN- } \\
111 \mathrm{~A}\end{array}$ & $13,600 \pm 230$ & Orlova 1979 \\
\hline & & & Volchiya Griva & Bone & SOAN-4292 & $14,280 \pm 285$ & Orlova et al. 2000a \\
\hline & & & Volchiya Griva & Bone & SOAN-4293 & $12,520 \pm 150$ & Orlova et al. 2000a \\
\hline 17 & 56.48 & 85.00 & Tomsk & Charcoal & GIN-2100 & $18,300 \pm 1,000$ & Tseitlin 1983 \\
\hline \multirow[t]{2}{*}{18} & \multirow[t]{2}{*}{57.73} & \multirow[t]{2}{*}{83.55} & $\begin{array}{l}\text { Mogochino 1, } \\
\text { cultural layer }\end{array}$ & Bone & SOAN-1513 & $20,150 \pm 240$ & Petrin 1986 \\
\hline & & & Denisova Cave, Layer 11 & Bone & SOAN-2504 & $>37,235$ & Derevianko et al. 1998 \\
\hline \multirow[t]{13}{*}{19} & \multirow[t]{13}{*}{51.38} & \multirow[t]{13}{*}{84.68} & Ust'-Karakol 1, Layer 10 & Charcoal & SOAN-3259 & $35,100 \pm 2,850$ & Derevianko et al. 1998 \\
\hline & & & Ust'-Karakol 1, Layer 9v & Charcoal & SOAN-3257 & $33,400 \pm 1,285$ & Derevianko et al. 1998 \\
\hline & & & Ust'-Karakol 1, Layer 9v & Charcoal & SOAN-3358 & $29,860 \pm 355$ & Derevianko et al. 1998 \\
\hline & & & Ust'-Karakol 1, Layer 9v & Charcoal & SOAN-3359 & $29,720 \pm 360$ & Derevianko et al. 1998 \\
\hline & & & Ust'-Karakol 1, Layer 5 & Charcoal & SOAN-3326 & $30,460 \pm 2,035$ & Kuzmin \& Orlova 1998 \\
\hline & & & Ust'-Karakol 1, Layer 5 & Charcoal & SOAN-3356 & $27,020 \pm 435$ & Derevianko et al. 1998 \\
\hline & & & Ust'-Karakol 1, Layer 5 & Charcoal & SOAN-3357 & $26,920 \pm 310$ & Derevianko et al. 1998 \\
\hline & & & Ust'-Karakol 1, Layer 5 & Charcoal & SOAN-3261 & $26,305 \pm 280$ & Derevianko et al. 1998 \\
\hline & & & Ust'-Karakol 1, Layer 4 & Humic acids & SOAN-3356 & $26,920 \pm 310$ & Kuzmin \& Orlova 1998 \\
\hline & & & $\begin{array}{l}\text { Ust'-Karakol 1, } \\
\text { Excavation 1, Layer } 3\end{array}$ & Charcoal & SOAN-2515 & $31,410 \pm 1,160$ & Derevianko et al. 1998 \\
\hline & & & $\begin{array}{l}\text { Ust'-Karakol 1, } \\
\text { Excavation 1, Layer } 3\end{array}$ & Charcoal & SOAN-2869 & $31,345 \pm 1,275$ & Derevianko et al. 1998 \\
\hline & & & $\begin{array}{l}\text { Ust'-Karakol 1, } \\
\text { Excavation 1, Layer } 3\end{array}$ & Charcoal & IGAN-837 & $29,900 \pm 2,070$ & Derevianko et al. 1998 \\
\hline & & & $\begin{array}{l}\text { Ust'-Karakol 1, } \\
\text { Excavation 1, Layer } 2\end{array}$ & Bone & SOAN-2614 & $28,700 \pm 850$ & Derevianko et al. 1998 \\
\hline 19a & 51.38 & 84.68 & Ust'-Karakol 2, Layer 3 & Bone & IGAN-1077 & $31,430 \pm 1,180$ & Derevianko et al. 1998 \\
\hline \multirow[t]{9}{*}{20} & \multirow{9}{*}{51.39} & \multirow{9}{*}{84.66} & Anyi 2, Layer 12 & Charcoal & IGAN-1425 & $27,930 \pm 1,590$ & Derevianko et al. 1998 \\
\hline & & & Anyi 2, Layer 12 & Charcoal & SOAN-3005 & $26,810 \pm 290$ & Derevianko et al. 1998 \\
\hline & & & Anyi 2, Layer 9 & Charcoal & SOAN-2868 & $27,125 \pm 580$ & Derevianko et al. 1998 \\
\hline & & & Anyi 2, Layer 8 & Charcoal & SOAN-3006 & $24,205 \pm 420$ & Derevianko et al. 1998 \\
\hline & & & Anyi 2, Layer 8 & Charcoal & SOAN-2862 & $22,610 \pm 140$ & Derevianko et al. 1998 \\
\hline & & & Anyi 2, Layer 8 & Charcoal & SOAN-2863 & $20,350 \pm 290$ & Derevianko et al. 1998 \\
\hline & & & Anyi 2, Layer 6 & Charcoal & IGAN-1430 & $23,431 \pm 1,550$ & Derevianko et al. 1998 \\
\hline & & & Anyi 2, Layer 4 & Charcoal & IGAN-1431 & $21,502 \pm 580$ & Derevianko et al. 1998 \\
\hline & & & Anyi 2, Layer 3 & Charcoal & SOAN-3007 & $21,280 \pm 440$ & Derevianko et al. 1998 \\
\hline \multirow[t]{6}{*}{21} & \multirow[t]{6}{*}{51.28} & \multirow[t]{6}{*}{84.47} & $\begin{array}{l}\text { Kaminnaya Cave, } \\
\text { Layer 14b }\end{array}$ & Bone & SOAN-3923 & $15,350 \pm 240$ & Derevianko et al. 2000a \\
\hline & & & $\begin{array}{l}\text { Kaminnaya Cave, } \\
\text { Layer 14a }\end{array}$ & Bone & SOAN-3922 & $14,550 \pm 230$ & Derevianko et al. 2000a \\
\hline & & & $\begin{array}{l}\text { Kaminnaya Cave, } \\
\text { Layer } 13\end{array}$ & Bone & SOAN-3921 & $14,120 \pm 95$ & Derevianko et al. 2000a \\
\hline & & & $\begin{array}{l}\text { Kaminnaya Cave, } \\
\text { Layer } 12\end{array}$ & Bone & SOAN-3920 & $13,870 \pm 390$ & Derevianko et al. 2000a \\
\hline & & & $\begin{array}{l}\text { Kaminnaya Cave, } \\
\text { Layer 11g }\end{array}$ & Bone & SOAN-3919 & $13,550 \pm 140$ & Derevianko et al. 2000a \\
\hline & & & $\begin{array}{l}\text { Kaminnaya Cave, } \\
\text { Layer } 11 \mathrm{v}\end{array}$ & Bone & SOAN-3918 & $12,160 \pm 225$ & Derevianko et al. 2000a \\
\hline 22 & 51.20 & 86.07 & Tyitkesken’ 3, Layer 6 & Charcoal & SOAN-2989 & $12,850 \pm 205$ & Derevianko et al. 1998 \\
\hline 23 & \multirow[t]{8}{*}{52.45} & \multirow[t]{8}{*}{86.92} & Dmitrievka, Strata 4 to 3 & Charcoal & SOAN-4233 & $14,750 \pm 250$ & Sulerzhitskiy et al. 1987 \\
\hline \multirow[t]{7}{*}{5} & & & Kara-Bom, Layer 6 & Charcoal & GX-17597 & $43,200 \pm 1,500^{*}$ & Derevianko et al. 1998 \\
\hline & & & Kara-Bom, Layer 5 & Charcoal & GX-17596 & $43,300 \pm 1,600^{*}$ & Derevianko et al. 1998 \\
\hline & & & Kara-Bom, Layer 4 & Charcoal & GX-17595 & $34,180 \pm 640 *$ & Derevianko et al. 1998 \\
\hline & & & Kara-Bom, Layer 4 & Charcoal & GX-17594 & $33,780 \pm 570^{*}$ & Derevianko et al. 1998 \\
\hline & & & Kara-Bom, Layer 3 & Charcoal & GX-17593 & $30,990 \pm 460 *$ & Derevianko et al. 1998 \\
\hline & & & $\begin{array}{l}\text { Kara-Bom, up from } \\
\text { Layer } 3\end{array}$ & Charcoal & GX-17592 & $38,080 \pm 910^{*}$ & Derevianko et al. 1998 \\
\hline & & & Kara-Bom & Charcoal & GIN-5935 & $33,800 \pm 600$ & Derevianko et al. 1998 \\
\hline
\end{tabular}


Table 1 Results from the updated ${ }^{14} \mathrm{C}$ Database of the Siberian Paleolithic

\begin{tabular}{|c|c|c|c|c|c|c|c|}
\hline & & & Kara-Bom, Layers 4 to 3 & Bone & GIN-5934 & $32,200 \pm 600$ & Derevianko et al. 1998 \\
\hline $\begin{array}{l}\text { Site } \\
\mathrm{nr}\end{array}$ & $\begin{array}{l}\text { Lat. } \\
\mathrm{N}\end{array}$ & $\begin{array}{l}\text { Long. } \\
\text { E }\end{array}$ & $\begin{array}{l}\text { Site name, } \\
\text { sample position }\end{array}$ & Material & Lab code & ${ }^{14} \mathrm{C}$ date $\mathrm{BP}$ & Reference \\
\hline \multirow[t]{5}{*}{24} & 51.05 & 86.30 & Kara-Tenesh & Charcoal & SOAN-2485 & $42,165 \pm 4,170$ & Derevianko et al. 1998 \\
\hline & & & Kara-Tenesh & Bone & SOAN-2135 & $34,760 \pm 1,240$ & Derevianko et al. 1998 \\
\hline & & & Kara-Tenesh & Bone & SOAN-2486 & $31,400 \pm 410$ & Derevianko et al. 1998 \\
\hline & & & Kara-Tenesh & Bone & SOAN-2134 & $26,875 \pm 625$ & Derevianko et al. 1998 \\
\hline & & & Kara-Tenesh & Charcoal & SOAN-3646 & $25,630 \pm 430$ & Derevianko et al. 1998 \\
\hline 25 & 50.42 & 86.52 & $\begin{array}{l}\text { Malyi Yaloman Cave, } \\
\text { Layer } 3\end{array}$ & Charcoal & SOAN-2500 & $33,350 \pm 1,145$ & Derevianko et al. 1998 \\
\hline \multirow[t]{21}{*}{26} & 55.90 & 87.95 & Shestakovo, Layer 24 & Bone & GrA-13238 & $25,660 \pm 200 *$ & Zenin et al. 2000c \\
\hline & & & Shestakovo, Layer 24 & Bone & GrA-13239 & $24,590 \pm 110 *$ & Zenin et al. 2000c \\
\hline & & & Shestakovo, Layer 22 & Bone & GrA-13235 & $23,330 \pm 110^{*}$ & Zenin et al. 2000c \\
\hline & & & Shestakovo, Layer 22 & Bone & SOAN-4177 & $22,500 \pm 280$ & Zenin et al. 2000c \\
\hline & & & Shestakovo, Layer 22 & Bone & SOAN-3612 & $22,240 \pm 185$ & Zenin et al. 2000c \\
\hline & & & Shestakovo, Layer 21 & Bone & SOAN-3611 & $21,300 \pm 420$ & Zenin et al. 2000c \\
\hline & & & Shestakovo, Layer 19 & Bone & GrA-10935 & $24,360 \pm 150 *$ & Zenin et al. 2000c \\
\hline & & & Shestakovo, Layer 19 & Charcoal & GrA-13233 & $23,250 \pm 110^{*}$ & Zenin et al. 2000c \\
\hline & & & Shestakovo, Layer 19 & Charcoal & AA-35322 & $23,290 \pm 200 *$ & Zenin et al. 2000c \\
\hline & & & Shestakovo, Layer 19 & Bone & GrA-13240 & $\begin{array}{l}22,340 \pm 180 / \\
170^{*}\end{array}$ & Zenin et al. 2000c \\
\hline & & & Shestakovo, Layer 19 & Charcoal & SOAN-3606 & $20,800 \pm 450$ & Zenin et al. 2000c \\
\hline & & & Shestakovo, Layer 19 & Bone & SOAN-3218 & $20,770 \pm 560$ & Zenin et al. 2000c \\
\hline & & & Shestakovo, Layer 19 & Bone & SOAN-3607 & $20,480 \pm 180$ & Zenin et al. 2000c \\
\hline & & & Shestakovo, Layer 19 & Bone & SOAN-3608 & $20,360 \pm 210$ & Zenin et al. 2000c \\
\hline & & & Shestakovo, Layer 17 & Bone & GrA-13234 & $21,560 \pm 100 *$ & Zenin et al. 2000c \\
\hline & & & Shestakovo, Layer 17 & Bone & SOAN-3609 & $19,190 \pm 310$ & Zenin et al. $2000 \mathrm{c}$ \\
\hline & & & Shestakovo, Layer 17 & Bone & SOAN-3610 & $18,040 \pm 175$ & Zenin et al. 2000c \\
\hline & & & Shestakovo & Bone & SOAN-1386 & $22,990 \pm 170$ & $\begin{array}{l}\text { Lisitsyn \& Svezhentsev } \\
1997\end{array}$ \\
\hline & & & Shestakovo & Bone & SOAN-1380 & $22,980 \pm 125$ & Lisitsyn 2000 \\
\hline & & & Shestakovo & Bone & LU-104 & $22,410 \pm 200$ & $\begin{array}{l}\text { Lisitsyn \& Svezhentsev } \\
1997\end{array}$ \\
\hline & & & Shestakovo & Charcoal & SOAN-1684 & $20,490 \pm 150$ & $\begin{array}{l}\text { Derevianko \& Zenin } \\
\text { 1995a }\end{array}$ \\
\hline \multicolumn{8}{|c|}{ The Yenisey River basin and adjacent areas } \\
\hline \multirow[t]{5}{*}{27} & 54.42 & 89.45 & Malaya Syia & Bone & SOAN-1286 & $34,500 \pm 500$ & Muratov et al. 1982 \\
\hline & & & Malaya Syia & Bone & SOAN-1287 & $34,420 \pm 360$ & Muratov et al. 1982 \\
\hline & & & Malaya Syia & Bone & AA- 8876 & $29,450 \pm 420^{*}$ & Kuzmin \& Orlova 1998 \\
\hline & & & Malaya Syia & Bone & LE-4918 & $25,250 \pm 1,200$ & Lisitsyn 2000 \\
\hline & & & Malaya Syia & Charcoal & SOAN-1124 & $20,300 \pm 350$ & Derevianko et al. 1992 \\
\hline 28 & 55.85 & 89.57 & Berezovyi Ruchei I & Bone & LE-4895 & $15,310 \pm 560$ & Lisitsyn 2000 \\
\hline 29 & 56.80 & 93.52 & $\begin{array}{l}\text { Druzhinikha, a surface } \\
\text { finding }\end{array}$ & Bone & LE-4894 & $43,580 \pm 8,800$ & Lisitsyn 2000 \\
\hline \multirow[t]{11}{*}{30} & 56.00 & 92.85 & $\begin{array}{l}\text { Afontova Gora 2, lower } \\
\text { humified lenses }\end{array}$ & Charcoal & GIN-117 & $20,900 \pm 300$ & Tseitlin 1979 \\
\hline & & & $\begin{array}{l}\text { Afontova Gora 2, below } \\
\text { Layer } 5\end{array}$ & Charcoal & GrA-5554 & $14,180 \pm 60 *$ & $\begin{array}{l}\text { Drozdov \& Artem'ev } \\
1997\end{array}$ \\
\hline & & & $\begin{array}{l}\text { Afontova Gora 2, below } \\
\text { Layer } 5\end{array}$ & Charcoal & GrA-5555 & $12,400 \pm 60 *$ & $\begin{array}{l}\text { Drozdov \& Artem'ev } \\
1997\end{array}$ \\
\hline & & & Afontova Gora 2, Layer 5 & Bone & SOAN-3251 & $15,130 \pm 795$ & Kuzmin \& Orlova 1998 \\
\hline & & & Afontova Gora 2, Layer 4 & Charcoal & SOAN-3075 & $14,070 \pm 110$ & $\begin{array}{l}\text { Drozdov \& Artem'ev } \\
1997\end{array}$ \\
\hline & & & Afontova Gora 2, Layer 4 & Charcoal & GIN-7541 & $13,930 \pm 80$ & $\begin{array}{l}\text { Drozdov \& Artem'ev } \\
1997\end{array}$ \\
\hline & & & Afontova Gora 2, Layer 4 & Charcoal & GIN-7540 & $13,650 \pm 70$ & $\begin{array}{l}\text { Drozdov \& Artem'ev } \\
1997\end{array}$ \\
\hline & & & $\begin{array}{l}\text { Afontova Gora 2, up from } \\
\text { Layer } 4\end{array}$ & Charcoal & GrN-22275 & $13,390 \pm 260 *$ & $\begin{array}{l}\text { Drozdov \& Artem'ev } \\
1997\end{array}$ \\
\hline & & & $\begin{array}{l}\text { Afontova Gora } 2 \text {, } \\
\text { Layer } 3 b\end{array}$ & Charcoal & SOAN-3077 & $14,330 \pm 95$ & $\begin{array}{l}\text { Drozdov \& Artem'ev } \\
1997\end{array}$ \\
\hline & & & $\begin{array}{l}\text { Afontova Gora } 2 \\
\text { Layer } 3 b\end{array}$ & Charcoal & GrN-22274 & $13,990 \pm 110 *$ & $\begin{array}{l}\text { Drozdov \& Artem'ev } \\
1997\end{array}$ \\
\hline & & & Afontova Gora 2, Layer 3 & Charcoal & GIN-7539 & $13,350 \pm 60$ & $\begin{array}{l}\text { Drozdov \& Artem'ev } \\
1997\end{array}$ \\
\hline
\end{tabular}


Table 1 Results from the updated ${ }^{14} \mathrm{C}$ Database of the Siberian Paleolithic

\begin{tabular}{|c|c|c|c|c|c|c|c|}
\hline $\begin{array}{l}\text { Site } \\
\mathrm{nr}\end{array}$ & $\begin{array}{l}\text { Lat. } \\
\mathrm{N}\end{array}$ & $\begin{array}{l}\text { Long. } \\
\text { E }\end{array}$ & $\begin{array}{l}\text { Site name, } \\
\text { sample position }\end{array}$ & Material & Lab code & ${ }^{14} \mathrm{C}$ date $\mathrm{BP}$ & Reference \\
\hline & & & Afontova Gora 2, Layer 2 & Charcoal & GrA-5556 & $14,200 \pm 60^{*}$ & $\begin{array}{l}\text { Drozdov \& Artem'ev } \\
1997\end{array}$ \\
\hline & & & Afontova Gora 2, Layer 2 & Charcoal & GIN-7542 & $13,330 \pm 140$ & $\begin{array}{l}\text { Drozdov \& Artem'ev } \\
1997\end{array}$ \\
\hline \multirow[t]{9}{*}{31} & 55.95 & 92.40 & Listvenka, Layer 19 & Charcoal & SOAN-3734 & $16,640 \pm 350$ & Akimova et al. 2000a \\
\hline & & & Listvenka, Layer 19 & Bone & GIN-6093 & $16,300 \pm 600$ & Drozdov 1992 \\
\hline & & & Listvenka, Layer 12 & Charcoal & Beta-58391 & $19,000 \pm 60^{*}$ & Akimova 1998 \\
\hline & & & Listvenka, Layer 12 & Charcoal & GIN-6965 & $13,100 \pm 410$ & Drozdov 1992 \\
\hline & & & Listvenka, Layer 9 & Charcoal & GIN-6967 & $14,170 \pm 80$ & Drozdov 1992 \\
\hline & & & Listvenka, Layer 8 & Charcoal & IGAN-1078 & $12,750 \pm 140$ & Drozdov 1992 \\
\hline & & & Listvenka, Layer 7 & Charcoal & GIN-6092 & $14,750 \pm 250$ & Drozdov 1992 \\
\hline & & & Listvenka, Layer 6 & Charcoal & SOAN-3463 & $13,850 \pm 485$ & Kuzmin \& Orlova 1998 \\
\hline & & & Listvenka, Layer 6 & Charcoal & IGAN-1079 & $13,580 \pm 350$ & Drozdov 1992 \\
\hline \multirow[t]{2}{*}{32} & 55.95 & 92.53 & $\begin{array}{l}\text { Bolshaya Slizneva, } \\
\text { Layer } 8\end{array}$ & Charcoal & SOAN-3315 & $13,540 \pm 500$ & Kuzmin \& Orlova 1998 \\
\hline & & & $\begin{array}{l}\text { Bolshaya Slizneva, } \\
\text { Layer } 7\end{array}$ & Bone & SOAN-3009 & $12,930 \pm 60$ & Kuzmin \& Orlova 1998 \\
\hline \multirow[t]{5}{*}{$33 \mathrm{a}$} & 55.87 & 92.20 & Biruisa 1, Layer 4 & Bone & LE-4962 & $14,700 \pm 270$ & $\begin{array}{l}\text { Kuz'mina \& Sinitsyna } \\
1995\end{array}$ \\
\hline & & & Biruisa 1, Layer 4 & Bone & LE-4910 & $14,680 \pm 400$ & $\begin{array}{l}\text { Kuz'mina \& Sinitsyna } \\
1995\end{array}$ \\
\hline & & & Biruisa 1, Layer 4 & Bone & GIN-8077 & $14,200 \pm 70$ & $\begin{array}{l}\text { Lisitsyn \& Svezhentsev } \\
1997\end{array}$ \\
\hline & & & Biruisa 1, Layer 4 & Bone & GIN-8075 & $13,840 \pm 90$ & $\begin{array}{l}\text { Lisitsyn \& Svezhentsev } \\
1997\end{array}$ \\
\hline & & & Biruisa 1, Layer 3a & Bone & LE-3777 & $14,480 \pm 400$ & $\begin{array}{l}\text { Kuz'mina \& Sinitsyna } \\
1995\end{array}$ \\
\hline \multirow[t]{5}{*}{$33 \mathrm{~b}$} & 55.97 & 92.48 & $\begin{array}{l}\text { Eleneva Cave, } \\
\text { Section no. } 1\end{array}$ & Bone & SOAN-3333 & $13,665 \pm 90$ & Kuzmin \& Orlova 1998 \\
\hline & & & $\begin{array}{l}\text { Eleneva Cave, } \\
\text { Section no. } 2\end{array}$ & Charcoal & SOAN-3307 & $12,050 \pm 325$ & Kuzmin \& Orlova 1998 \\
\hline & & & $\begin{array}{l}\text { Eleneva Cave, } \\
\text { Section no. } 2\end{array}$ & Charcoal & SOAN-3308 & $12,040 \pm 160$ & Kuzmin \& Orlova 1998 \\
\hline & & & $\begin{array}{l}\text { Eleneva Cave, } \\
\text { Section no. } 2\end{array}$ & Charcoal & SOAN-3309 & $12,085 \pm 105$ & Kuzmin \& Orlova 1998 \\
\hline & & & Eleneva Cave, Layer 18 & Bone & SOAN-3252 & $12,040 \pm 150$ & Orlova et al. 2000b \\
\hline \multirow[t]{4}{*}{9} & & & $\begin{array}{l}\text { Dvuglazka Rockshelter, } \\
\text { Layer } 4\end{array}$ & Bone & LE-4808 & $26,580 \pm 520$ & Lisitsyn 2000 \\
\hline & & & Dvuglazka Rockshelter & Bone & LE-1433 & $22,500 \pm 600$ & Arslanov et al. 1981 \\
\hline & & & Dvuglazka Rockshelter & Bone & LE-1433 & $20,190 \pm 140$ & Arslanov et al. 1981 \\
\hline & & & Dvuglazka Rockshelter & Bone & LE-1433 & $19,880 \pm 200$ & Arslanov et al. 1981 \\
\hline \multirow[t]{2}{*}{34} & 55.32 & 92.50 & Derbina 5 & Charcoal & SOAN-4201 & $32,430 \pm 1,540$ & Akimova et al. 2000b \\
\hline & & & Derbina 5 & Charcoal & SOAN-4200 & $29,230 \pm 940$ & Akimova et al. 2000b \\
\hline \multirow[t]{4}{*}{35} & 54.58 & 91.07 & $\begin{array}{l}\text { Sabanikha, a surface } \\
\text { finding }\end{array}$ & Antler & LE-3747 & $25,950 \pm 500$ & Lisitsyn 2000 \\
\hline & & & Sabanikha & Charcoal & LE-4796 & $25,440 \pm 450$ & Lisitsyn 2000 \\
\hline & & & Sabanikha & Charcoal & LE-3611 & $22,930 \pm 350$ & Svezhentsev et al. 1992 \\
\hline & & & Sabanikha & Charcoal & LE-4701 & $22,900 \pm 480$ & Svezhentsev et al. 1992 \\
\hline \multirow[t]{7}{*}{11} & & & Kurtak 4 , Strata 12 to 11 & Charcoal & LE-2833 & $27,470 \pm 200$ & Svezhentsev et al. 1992 \\
\hline & & & Kurtak 4, Stratum 11 & Bone & LE-3357 & $24,890 \pm 670$ & Svezhentsev et al. 1992 \\
\hline & & & Kurtak 4, Stratum 11 & Charcoal & GIN-5350 & $24,800 \pm 400$ & Svezhentsev et al. 1992 \\
\hline & & & Kurtak 4, Stratum 11 & Charcoal & LE-3351 & $24,170 \pm 230$ & Svezhentsev et al. 1992 \\
\hline & & & Kurtak 4, Stratum 11 & Bone & LE-4156 & $24,000 \pm 2,950$ & Svezhentsev et al. 1992 \\
\hline & & & Kurtak 4, Stratum 11 & Charcoal & LE-4155 & $23,800 \pm 900$ & Svezhentsev et al. 1992 \\
\hline & & & Kurtak 4, Stratum 11 & Charcoal & LE-2833 & $23,470 \pm 200$ & Svezhentsev et al. 1992 \\
\hline \multirow[t]{3}{*}{36} & 54.97 & 90.95 & Novoselovo 13, Layer 3 & Charcoal & LE-3739 & $22,000 \pm 700$ & Svezhentsev et al. 1992 \\
\hline & & & Novoselovo 13, Layer 1 & Bone & LE-4896 & $15,030 \pm 620$ & Lisitsyn 2000 \\
\hline & & & Novoselovo 13, Layer 1 & Bone & LE-4805 & $13,630 \pm 200$ & Lisitsyn 2000 \\
\hline \multirow[t]{3}{*}{37} & 55.15 & 91.55 & $\begin{array}{l}\text { Kashtanka 1, buried soils } \\
\text { (below cultural layer) }\end{array}$ & Charcoal & GrN-24482 & $36,130 \pm 510^{*}$ & Drozdov et al. 2000 \\
\hline & & & $\begin{array}{l}\text { Kashtanka 1, buried soils } \\
\text { (below cultural layer) }\end{array}$ & Charcoal & GrN-24481 & $28,320 \pm 190 *$ & Drozdov et al. 2000 \\
\hline & & & $\begin{array}{l}\text { Kashtanka 1, below the } \\
\text { main layer }\end{array}$ & Charcoal & GIN-6999 & $29,400 \pm 400$ & Derevianko et al. 1992 \\
\hline
\end{tabular}


Table 1 Results from the updated ${ }^{14} \mathrm{C}$ Database of the Siberian Paleolithic

\begin{tabular}{|c|c|c|c|c|c|c|c|}
\hline $\begin{array}{l}\text { Site } \\
\mathrm{nr}\end{array}$ & $\begin{array}{l}\text { Lat. } \\
\mathrm{N}\end{array}$ & $\begin{array}{l}\text { Long. } \\
\text { E }\end{array}$ & $\begin{array}{l}\text { Site name, } \\
\text { sample position }\end{array}$ & Material & Lab code & ${ }^{14} \mathrm{C}$ date $\mathrm{BP}$ & Reference \\
\hline & & & $\begin{array}{l}\text { Kashtanka } 1 \text {, below the } \\
\text { main layer }\end{array}$ & Charcoal & IGAN-1048 & $24,400 \pm 1,500$ & Derevianko et al. 1992 \\
\hline & & & $\begin{array}{l}\text { Kashtanka 1, below the } \\
\text { main layer }\end{array}$ & Charcoal & IGAN-1050 & $23,830 \pm 850$ & Derevianko et al. 1992 \\
\hline & & & Kashtanka 1, Main Layer & Charcoal & SOAN-2853 & $24,805 \pm 425$ & Derevianko et al. 1992 \\
\hline & & & Kashtanka 1, Main Layer & Charcoal & IGAN-1049 & $21,800 \pm 200$ & Derevianko et al. 1992 \\
\hline & & & Kashtanka 1, Main Layer & Charcoal & GIN-6968 & $20,800 \pm 600$ & Derevianko et al. 1992 \\
\hline \multirow[t]{2}{*}{38} & 55.22 & 91.95 & $\begin{array}{l}\text { Shlenka, a surface } \\
\text { finding }\end{array}$ & Tusk & GIN-2863 & $20,100 \pm 100$ & Astakhov et al. 1993 \\
\hline & & & $\begin{array}{l}\text { Shlenka, a surface find- } \\
\text { ing }\end{array}$ & Tusk & GIN-2862 & $18,600 \pm 2,000$ & Astakhov et al. 1993 \\
\hline \multirow[t]{2}{*}{39} & 55.05 & 91.05 & $\begin{array}{l}\text { Tarachikha, Loc. 1, } \\
\text { a surface finding }\end{array}$ & Bone & LE-3821 & $19,850 \pm 180$ & Lisitsyn 2000 \\
\hline & & & $\begin{array}{l}\text { Tarachikha, Loc. 1, } \\
\text { a surface finding }\end{array}$ & Bone & LE-3834 & $18,930 \pm 320$ & Lisitsyn 2000 \\
\hline 40 & 54.93 & 90.93 & $\begin{array}{l}\text { Kokorevo 4A, Layers } 5 \text { to } \\
3\end{array}$ & Charcoal & LE-469 & $14,320 \pm 330$ & Abramova 1979a \\
\hline \multirow[t]{2}{*}{41} & 54.94 & 90.93 & Kokorevo 2 & Charcoal & GIN-90 & $13,300 \pm 100$ & Abramova 1979a \\
\hline & & & Kokorevo 2 & Bone & LE-4812 & $12,090 \pm 100$ & Lisitsyn 2000 \\
\hline \multirow[t]{4}{*}{42} & 55.16 & 91.57 & Kurtak 3 & Charcoal & GIN-2102 & $16,900 \pm 700$ & Abramova et al. 1991 \\
\hline & & & Kurtak 3 & Charcoal & GIN-2101 & $14,600 \pm 200$ & Abramova et al. 1991 \\
\hline & & & Kurtak 3 & Charcoal & LE-1456 & $14,390 \pm 100$ & Abramova et al. 1991 \\
\hline & & & Kurtak 3 & Charcoal & LE-1457 & $14,300 \pm 100$ & Abramova et al. 1991 \\
\hline 43 & 55.03 & 91.00 & Divnyi 1 & Bone & LE-4806 & $13,220 \pm 150$ & Lisitsyn 2000 \\
\hline \multirow[t]{2}{*}{44} & 54.60 & 91.02 & Tashtyk 1, Layer 1 & Bone & LE-4980 & $12,880 \pm 130$ & Lisitsyn 2000 \\
\hline & & & Tashtyk 1, Layer 1 & Charcoal & LE-771 & $12,180 \pm 120$ & Abramova 1979a \\
\hline 45 & 54.61 & 91.01 & Tashtyk 2, Layer 2 & Bone & LE-4801 & $13,550 \pm 320$ & Lisitsyn 2000 \\
\hline 46 & 54.58 & 91.00 & Tashtyk 4 & Charcoal & GIN-262 & $14,700 \pm 150$ & Abramova 1979a \\
\hline 47 & 54.93 & 90.94 & Kokorevo 3 & Charcoal & LE-629 & $12,690 \pm 140$ & Abramova 1979a \\
\hline \multirow[t]{7}{*}{48} & 54.93 & 90.92 & Kokorevo 1, Layer 3 & Charcoal & IGAN-104 & $15,900 \pm 250$ & Abramova 1979b \\
\hline & & & Kokorevo 1, Layer 3 & Charcoal & LE-628 & $14,450 \pm 150$ & Abramova 1979b \\
\hline & & & Kokorevo 1, Layer 3 & Charcoal & GIN-91 & $13,300 \pm 50$ & Abramova 1979b \\
\hline & & & Kokorevo 1, Layer 3 & Bone & IGAN-102 & $13,000 \pm 50$ & Abramova 1979b \\
\hline & & & Kokorevo 1, Layer 2 & Charcoal & IGAN-105 & $15,200 \pm 200$ & Abramova 1979b \\
\hline & & & Kokorevo 1, Layer 2 & Bone & IGAN-103 & $13,100 \pm 500$ & Abramova 1979b \\
\hline & & & Kokorevo 1, Layer 2 & Charcoal & LE-526 & $12,940 \pm 270$ & Abramova 1979b \\
\hline 49 & 54.95 & 90.93 & $\begin{array}{l}\text { Kokorevo 4B, the lower } \\
\text { layer }\end{array}$ & Bone & LE-540 & $15,460 \pm 320$ & Abramova 1979a \\
\hline \multirow[t]{2}{*}{50} & 55.03 & 90.97 & Novoselovo 6 & Bone & LE-4807 & $18,090 \pm 940$ & Lisitsyn 2000 \\
\hline & & & Novoselovo 6 & Bone & LE-5045 & $13,570 \pm 140$ & Lisitsyn 2000 \\
\hline \multirow[t]{3}{*}{51} & 55.03 & 90.98 & Novoselovo 7 & Bone & LE-4802 & $15,950 \pm 120$ & Lisitsyn 2000 \\
\hline & & & Novoselovo 7 & Charcoal & GIN-402 & $15,000 \pm 300$ & Abramova $1979 \mathrm{~b}$ \\
\hline & & & Novoselovo 7 & Bone & LE-4803 & $14,220 \pm 170$ & Lisitsyn 2000 \\
\hline 52 & 54.63 & 90.90 & $\begin{array}{l}\text { Pervomaiskoe } 1 \text {, a sur- } \\
\text { face finding }\end{array}$ & Bone & LE-4893 & $12,870 \pm 140$ & Lisitsyn 2000 \\
\hline 53 & 53.95 & 91.83 & Pritubinsk, Layer 3 & Charcoal & SOAN-2854 & $15,600 \pm 495$ & Orlova 1995 \\
\hline 54 & 53.22 & 90.80 & $\begin{array}{l}\text { Ulug-Bil', a surface } \\
\text { finding }\end{array}$ & Bone & LE-1404 & $15,020 \pm 150$ & Lisitsyn 2000 \\
\hline \multirow[t]{4}{*}{55} & 52.97 & 91.43 & Ui 1, Layer 2 & Charcoal & LE-4189 & $22,830 \pm 530$ & Vasil'ev 1996 \\
\hline & & & Ui 1, Layer 2 & Bone & LE-4257 & $19,280 \pm 200$ & Vasil'ev 1996 \\
\hline & & & Ui 1, Layer 2 & Bone & LE-3359 & $17,520 \pm 130$ & Vasil'ev 1996 \\
\hline & & & Ui 1, Layer 2 & Bone & LE-3358 & $16,760 \pm 120$ & Vasil'ev 1996 \\
\hline 56 & 52.08 & 92.35 & Nizhny Idzhir 1 & Charcoal & LE-1984 & $17,200 \pm 140$ & Astakhov 1986 \\
\hline \multirow[t]{2}{*}{57} & 53.08 & 91.42 & Oznachennoye 1 & Bone & LE-1404 & $15,020 \pm 150$ & Astakhov 1986 \\
\hline & & & Oznachennoye 1 & Bone & LE-1404 & $14,100 \pm 150$ & Svezhentsev et al. 1992 \\
\hline \multirow[t]{7}{*}{58} & 52.97 & 91.45 & Mayiniskaya, Layer 5 & Bone & LE-2135 & $16,540 \pm 170$ & Vasil'ev 1996 \\
\hline & & & Mayiniskaya, Layer 5 & Bone & LE-2135 & $16,176 \pm 180$ & Vasil'ev 1996 \\
\hline & & & Mayiniskaya, Layer 4 & Bone & LE-4251 & $13,690 \pm 390$ & Vasil'ev 1996 \\
\hline & & & Mayniskaya, Layer 4 & Bone & LE-2133 & $12,910 \pm 100$ & Vasil'ev 1996 \\
\hline & & & Mayiniskaya, Layer 3 & Bone & LE-2149 & $14,070 \pm 150$ & Vasil'ev 1996 \\
\hline & & & Mayiniskaya, Layer 3 & Bone & LE-2149 & $13,900 \pm 150$ & Vasil'ev 1996 \\
\hline & & & Mayiniskaya, Layer 3 & Bone & LE-2149 & $12,330 \pm 150$ & Vasil'ev 1996 \\
\hline
\end{tabular}


Table 1 Results from the updated ${ }^{14} \mathrm{C}$ Database of the Siberian Paleolithic

\begin{tabular}{|c|c|c|c|c|c|c|c|}
\hline $\begin{array}{l}\text { Site } \\
\mathrm{nr}\end{array}$ & $\begin{array}{l}\text { Lat. } \\
\mathrm{N}\end{array}$ & $\begin{array}{l}\text { Long. } \\
\text { E }\end{array}$ & $\begin{array}{l}\text { Site name, } \\
\text { sample position }\end{array}$ & Material & Lab code & ${ }^{14} \mathrm{C}$ date $\mathrm{BP}$ & Reference \\
\hline & & & Mayiniskaya, Layer 3 & Bone & LE-4252 & $12,120 \pm 650$ & Vasil'ev 1996 \\
\hline & & & Mayiniskaya, Layer 2-2 & Charcoal & LE-2378 & $10,800 \pm 200$ & Vasil'ev 1996 \\
\hline & & & Mayiniskaya, Layer 2-1 & Bone & LE-2300 & $12,280 \pm 150$ & Vasil'ev 1996 \\
\hline & & & Mayiniskaya, Layer 2-1 & Bone & LE-2300 & $12,120 \pm 120$ & Vasil'ev 1996 \\
\hline & & & Mayiniskaya, Layer 1 & Bone & LE-2299 & $15,500 \pm 150$ & Vasil'ev 1996 \\
\hline & & & Mayiniskaya, Layer B & Charcoal & LE-2383 & $15,200 \pm 150$ & Vasil'ev 1996 \\
\hline & & & $\begin{array}{l}\text { Mayiniskaya, Layers A3 } \\
\text { to A1 }\end{array}$ & Bone & LE-3019 & $11,700 \pm 100$ & Vasil'ev 1996 \\
\hline & & & Mayiniskaya, Layer A1 & Bone & LE-4255 & $12,110 \pm 220$ & Vasil'ev 1996 \\
\hline 59 & 52.97 & 91.44 & Ui 2, Layer 6 & Charcoal & LE-3717 & $14,310 \pm 3,600$ & Lisitsyn 2000 \\
\hline \multirow[t]{4}{*}{60} & 52.98 & 91.52 & Golubaya 1, Layer 3 & Charcoal & LE-1101d & $13,650 \pm 180$ & Astakhov 1986 \\
\hline & & & Golubaya 1, Layer 3 & Charcoal & LE-1101a & $13,050 \pm 90$ & Astakhov 1986 \\
\hline & & & Golubaya 1, Layer 3 & Bone & LE-1101b & $12,900 \pm 150$ & Astakhov 1986 \\
\hline & & & Golubaya 1, Layer 3 & Bone & LE-1101c & $12,980 \pm 140$ & Astakhov 1986 \\
\hline 61 & 56.03 & 95.88 & Brazhnoe & Bone & GIN-8481 & $>31,000$ & Vorob'eva et al. 1998 \\
\hline \multirow[t]{4}{*}{62} & 56.18 & 95.92 & $\begin{array}{l}\text { Strizhovaya Gora, Layer } \\
18\end{array}$ & Bone & GIN-5326 & $14,000 \pm 1,500$ & Generalov 2000 \\
\hline & & & $\begin{array}{l}\text { Strizhovaya Gora, Layer } \\
16 \text { to } 14\end{array}$ & Bone & GIN-5820 & $12,250 \pm 150$ & Generalov 2000 \\
\hline & & & $\begin{array}{l}\text { Strizhovaya Gora, Layer } \\
16 \text { to } 14\end{array}$ & Bone & GIN-5822 & $12,090 \pm 120$ & Generalov 2000 \\
\hline & & & $\begin{array}{l}\text { Strizhovaya Gora, Layer } \\
16 \text { to } 14\end{array}$ & Bone & GIN-5821 & $12,000 \pm 150$ & Generalov 2000 \\
\hline \multicolumn{8}{|c|}{ The Angara River basin and the Lena River headwaters } \\
\hline \multirow[t]{9}{*}{63} & 58.30 & 100.33 & $\begin{array}{l}\text { Ust'-Kova, Lower } \\
\text { Component }\end{array}$ & Charcoal & GIN-5929 & $34,300 \pm 900$ & Drozdov et al. 1990 \\
\hline & & & $\begin{array}{l}\text { Ust'-Kova, Lower } \\
\text { Component }\end{array}$ & Charcoal & SOAN-1690 & $>32,850$ & Drozdov et al. 1990 \\
\hline & & & $\begin{array}{l}\text { Ust'-Kova, Lower } \\
\text { Component }\end{array}$ & Charcoal & GIN-1741 & $30,100 \pm 150$ & Drozdov et al. 1990 \\
\hline & & & $\begin{array}{l}\text { Ust'-Kova, Lower } \\
\text { Component }\end{array}$ & Charcoal & SOAN-1875 & $28,050 \pm 670$ & Drozdov et al. 1990 \\
\hline & & & $\begin{array}{l}\text { Ust'-Kova, Lower } \\
\text { Component }\end{array}$ & Charcoal & SOAN-1900 & $19,540 \pm 90$ & Drozdov et al. 1990 \\
\hline & & & $\begin{array}{l}\text { Ust'-Kova, Middle } \\
\text { Component }\end{array}$ & Charcoal & KRIL-381 & $23,920 \pm 310$ & Drozdov et al. 1990 \\
\hline & & & $\begin{array}{l}\text { Ust'-Kova, Middle } \\
\text { Component }\end{array}$ & Bone & LE-3820 & $13,860 \pm 680$ & Lisitsyn 2000 \\
\hline & & & $\begin{array}{l}\text { Ust'-Kova, Upper } \\
\text { Component }\end{array}$ & Charcoal & LE-1372 & $14,220 \pm 110$ & Drozdov et al. 1990 \\
\hline & & & Ust'-Kova, depth $1.5 \mathrm{~m}$ & Charcoal & KRIL-621 & $18,035 \pm 180$ & Starikov et al. 1991 \\
\hline 64 & 52.30 & 104.17 & Mamony 2, Layer 4 & Bone & GIN-8480 & $31,400 \pm 150$ & Vorob'eva et al. 1998 \\
\hline 65 & 52.30 & 104.32 & Voenny Hospital & Bone & GIN-4410 & $29,700 \pm 500$ & Medvedev et al. 1990 \\
\hline \multirow[t]{4}{*}{66} & 53.58 & 103.42 & $\begin{array}{l}\text { Igeteisky Log I, } \\
\text { Stratum } 6\end{array}$ & Bone & GIN-4327 & $24,400 \pm 100$ & Medvedev et al. 1990 \\
\hline & & & $\begin{array}{l}\text { Igeteisky Log I, } \\
\text { Stratum } 4\end{array}$ & Charcoal & IM-405 & $23,760 \pm 1,100$ & Medvedev et al. 1990 \\
\hline & & & $\begin{array}{l}\text { Igeteisky Log I, } \\
\text { Stratum } 4\end{array}$ & Charcoal & LE-1592 & $23,508 \pm 250$ & Medvedev et al. 1990 \\
\hline & & & $\begin{array}{l}\text { Igeteisky Log I, } \\
\text { Stratum } 4\end{array}$ & Charcoal & LE-1590 & $21,260 \pm 240$ & Medvedev et al. 1990 \\
\hline \multirow[t]{11}{*}{67} & 52.83 & 103.53 & Malta, Stratum 6 & Bone & OxA-6189 & $43,100 \pm 2,400 *$ & Medvedev et al. 1996 \\
\hline & & & Malta, gravel & Bone & GIN-7707 & $41,100 \pm 1,500$ & Medvedev et al. 1996 \\
\hline & & & $\begin{array}{l}\text { Malta, contact between } \\
\text { Strata } 7 \text { and } 3\end{array}$ & Bone & OxA-6190 & $25,760 \pm 260 *$ & Medvedev et al. 1996 \\
\hline & & & Malta, Stratum 8 & Bone & OxA-6191 & $21,700 \pm 160 *$ & Medvedev et al. 1996 \\
\hline & & & Malta, Stratum 8 & Bone & GIN-7708 & $21,600 \pm 200$ & Medvedev et al. 1996 \\
\hline & & & Malta, Stratum 8 & Bone & GIN-8475 & $21,600 \pm 170$ & Medvedev et al. 1996 \\
\hline & & & Malta, Stratum 8 & Bone & OxA-6193 & $21,340 \pm 340 *$ & Medvedev et al. 1996 \\
\hline & & & Malta, Stratum 8 & Bone & GIN-7704 & $21,300 \pm 300$ & Medvedev et al. 1996 \\
\hline & & & Malta, Stratum 8 & Bone & GIN-7702 & $21,300 \pm 110$ & Medvedev et al. 1996 \\
\hline & & & Malta, Stratum 8 & Bone & GIN-7703 & $21,100 \pm 150$ & Medvedev et al. 1996 \\
\hline & & & Malta, Stratum 8 & Bone & GIN-7706 & $21,000 \pm 140$ & Medvedev et al. 1996 \\
\hline
\end{tabular}


Table 1 Results from the updated ${ }^{14} \mathrm{C}$ Database of the Siberian Paleolithic

\begin{tabular}{|c|c|c|c|c|c|c|c|}
\hline $\begin{array}{l}\text { Site } \\
\mathrm{nr}\end{array}$ & $\begin{array}{l}\text { Lat. } \\
\mathrm{N}\end{array}$ & $\begin{array}{l}\text { Long. } \\
\text { E }\end{array}$ & $\begin{array}{l}\text { Site name, } \\
\text { sample position }\end{array}$ & Material & Lab code & ${ }^{14} \mathrm{C}$ date $\mathrm{BP}$ & Reference \\
\hline & & & Malta, Stratum 8 & Bone & GIN-7710 & $20,800 \pm 140$ & Medvedev et al. 1996 \\
\hline & & & Malta, Stratum 8 & Bone & OxA-6192 & $20,340 \pm 320 *$ & Medvedev et al. 1996 \\
\hline & & & Malta, Stratum 8 & Bone & GIN-7705 & $19,900 \pm 800$ & Medvedev et al. 1996 \\
\hline & & & Malta, washed sediments & Bone & GIN-7709 & $20,700 \pm 150$ & Medvedev et al. 1996 \\
\hline & & & Malta, Stratum 9 & Tusk & GIN-8476 & $14,720 \pm 190$ & Medvedev et al. 1996 \\
\hline & & & $\begin{array}{l}\text { Malta, main cultural } \\
\text { layer }\end{array}$ & Bone & GIN-4367 & $20,900 \pm 200$ & Medvedev et al. 1996 \\
\hline & & & $\begin{array}{l}\text { Malta, main cultural } \\
\text { layer }\end{array}$ & Bone & GIN-4367 & $20,800 \pm 200$ & Medvedev et al. 1996 \\
\hline & & & Malta & Bone & GIN-87 & $14,750 \pm 120$ & Tseitlin 1979 \\
\hline 68 & 53.00 & 103.50 & Buret' & Bone & SOAN-1680 & $21,190 \pm 100$ & Abramova 1989 \\
\hline 69 & 53.67 & 103.43 & Krasny Yar 1, Layer 6 & Bone & GIN-5330 & $19,100 \pm 100$ & Medvedev et al. 1991 \\
\hline \multirow[t]{2}{*}{70} & 52.87 & 103.43 & Sosnovy Bor, Layer 3b & Bone & GIN-5328 & $12,060 \pm 120$ & Vorob'eva 1991 \\
\hline & & & Sosnovy Bor, Layer 4 & Bone & AA-38038 & $12,090 \pm 110^{*}$ & This paper \\
\hline 71 & 52.37 & 104.28 & $\begin{array}{l}\text { Verkholenskaya Gora } 1 \text {, } \\
\text { Layer 3d }\end{array}$ & Charcoal & Mo-441 & $12,570 \pm 180$ & Medvedev et al. 1990 \\
\hline \multirow[t]{3}{*}{72} & 54.00 & 105.82 & Makarovo 4, Layer 3a & Bone & AA- 8800 & $>39,000^{*}$ & Goebel \& Aksenov 1995 \\
\hline & & & Makarovo 4, Layer 3a & Bone & AA- 8878 & $>38,000 *$ & Goebel \& Aksenov 1995 \\
\hline & & & Makarovo 4, Layer 3a & Bone & AA-8879 & $>38,000^{*}$ & Goebel \& Aksenov 1995 \\
\hline 73 & 54.02 & 105.80 & Makarovo 3 & Bone & GIN-7067b & $31,200 \pm 500$ & Aksenov 1993 \\
\hline 74 & 54.02 & 105.67 & Shishkino 8 & Bone & AA- 8882 & $21,190 \pm 175^{*}$ & Aksenov 1993 \\
\hline 75 & 54.03 & 105.82 & Makarovo 2, Layer 4 & Charcoal & GIN-481 & $11,950 \pm 50$ & Medvedev et al. 1990 \\
\hline 76 & 54.03 & 105.78 & Shishkino 2, Layer 3 & Charcoal & GIN-5634 & $13,900 \pm 200$ & Aksenov 1996 \\
\hline 77 & 57.48 & 107.77 & Balyshevo 3, Layer 2 & Bone & LE-3950 & $25,100 \pm 940$ & $\begin{array}{l}\text { Lisitsyn \& Svezhentsev } \\
1997\end{array}$ \\
\hline 78 & 57.83 & 108.37 & Alexeevsk 1 & Charcoal & LE-3931 & $22,415 \pm 480$ & Zadonin 1996 \\
\hline \multirow[t]{4}{*}{79} & 55.65 & 109.35 & Kurla 3, Layer 2 & Charcoal & SOAN-1397 & $24,060 \pm 5,700$ & $\begin{array}{l}\text { Shmygun \& Filippov } \\
1982\end{array}$ \\
\hline & & & Kurla 3, Layer 1 & Bone & SOAN-1396 & $15,200 \pm 1,250$ & $\begin{array}{l}\text { Shmygun \& Filippov } \\
1982\end{array}$ \\
\hline & & & Kurla 3, Layer 1 & Bone & SOAN-1396 & $13,160 \pm 350$ & Ineshin 1993 \\
\hline & & & Kurla 6 & Charcoal & SOAN-1398 & $14,150 \pm 960$ & $\begin{array}{l}\text { Shmygun \& Filippov } \\
1982\end{array}$ \\
\hline \multirow[t]{15}{*}{80} & 57.83 & 114.00 & Bolshoi Yakor 1, Layer 9 & Charcoal & GIN-8470 & $12,700 \pm 400$ & Belousov et al. 1997 \\
\hline & & & Bolshoi Yakor 1, Layer 8 & Charcoal & GIN-6468 & $12,630 \pm 230$ & Belousov et al. 1997 \\
\hline & & & Bolshoi Yakor 1, Layer 7 & Bone & GIN-6467 & $12,380 \pm 250$ & Belousov et al. 1997 \\
\hline & & & Bolshoi Yakor 1, Layer 7 & Charcoal & GIN-6466 & $12,330 \pm 250$ & Belousov et al. 1997 \\
\hline & & & Bolshoi Yakor 1, Layer 6 & Charcoal & GIN-7712 & $15,900 \pm 270$ & Belousov et al. 1997 \\
\hline & & & Bolshoi Yakor 1, Layer 6 & Charcoal & LE-4172 & $12,400 \pm 150$ & Belousov et al. 1997 \\
\hline & & & Bolshoi Yakor 1, Layer 6 & Bone & GIN-6425 & $12,380 \pm 200$ & Belousov et al. 1997 \\
\hline & & & Bolshoi Yakor 1, Layer 5 & Charcoal & GIN-7711 & $17,840 \pm 290$ & Belousov et al. 1997 \\
\hline & & & Bolshoi Yakor 1, Layer 5 & Charcoal & GIN-8470 & $12,700 \pm 140$ & Belousov et al. 1997 \\
\hline & & & Bolshoi Yakor 1, Layer 5 & Charcoal & GIN-8473 & $12,700 \pm 90$ & Belousov et al. 1997 \\
\hline & & & Bolshoi Yakor 1, Layer 5 & Charcoal & GIN-7713 & $12,530 \pm 90$ & Belousov et al. 1997 \\
\hline & & & Bolshoi Yakor 1, Layer 5 & Charcoal & GIN-8471 & $12,200 \pm 80$ & Belousov et al. 1997 \\
\hline & & & Bolshoi Yakor 1, Layer 5 & Charcoal & GIN-8472 & $12,050 \pm 120$ & Belousov et al. 1997 \\
\hline & & & $\begin{array}{l}\text { Bolshoi Yakor 1, } \\
\text { Layer 3v }\end{array}$ & Charcoal & GIN-6460A & $12,080 \pm 220$ & Belousov et al. 1997 \\
\hline & & & $\begin{array}{l}\text { Bolshoi Yakor 1, } \\
\text { Layer 3v }\end{array}$ & Charcoal & GIN-6460 & $12,000 \pm 250$ & Belousov et al. 1997 \\
\hline \multirow[t]{2}{*}{81} & 57.83 & 114.09 & $\begin{array}{l}\text { Avdeikha, depth } 0.8 \text { to } \\
1.2 \mathrm{~m}\end{array}$ & Charcoal & IM-236 & $15,200 \pm 300$ & Kostiukevich et al. 1977 \\
\hline & & & $\begin{array}{l}\text { Avdeikha, depth } 0.8 \text { to } \\
1.2 \mathrm{~m}\end{array}$ & Charcoal & GIN-1022 & $12,900 \pm 300$ & Kind et al. 1976 \\
\hline 82 & 55.63 & 115.87 & $\begin{array}{l}\text { Nizhniaya Dzhilinda 1, } \\
\text { Layer } 7\end{array}$ & Charcoal & GIN-6466 & $12,330 \pm 250$ & $\begin{array}{l}\text { Kuzmin \& Tankersley } \\
1996\end{array}$ \\
\hline \multirow[t]{4}{*}{83} & 54.47 & 116.52 & Ust'-Karenga 12, Layer 8 & Bone & GIN-8668 & $16,430 \pm 240$ & Vetrov 1995 \\
\hline & & & Ust'-Karenga 12, Layer 8 & Bone & GIN-8070 & $13,560 \pm 1,950$ & Vetrov 1995 \\
\hline & & & Ust'-Karenga 12, Layer 8 & Bone & GIN-6469 & $12,880 \pm 130$ & Vetrov 1995 \\
\hline & & & Ust'-Karenga 12, Layer 8 & Bone & GIN-8069 & $12,710 \pm 380$ & Vetrov 1995 \\
\hline \multicolumn{8}{|c|}{ The Transbaikal } \\
\hline 84 & 50.53 & 106.30 & Ust'-Kyakhta 4, Layer 2 & Bone & SOAN-1553 & $12,595 \pm 150$ & Okladnikov 1981 \\
\hline
\end{tabular}


Table 1 Results from the updated ${ }^{14} \mathrm{C}$ Database of the Siberian Paleolithic

\begin{tabular}{|c|c|c|c|c|c|c|c|}
\hline $\begin{array}{l}\text { Site } \\
\mathrm{nr}\end{array}$ & $\begin{array}{l}\text { Lat. } \\
\mathrm{N}\end{array}$ & $\begin{array}{l}\text { Long. } \\
\text { E }\end{array}$ & $\begin{array}{l}\text { Site name, } \\
\text { sample position }\end{array}$ & Material & Lab code & ${ }^{14} \mathrm{C}$ date $\mathrm{BP}$ & Reference \\
\hline \multirow[t]{2}{*}{85} & 50.53 & 106.32 & Ust'-Kyakhta 17, Layer 5 & Bone & GIN-8493b & $12,230 \pm 100$ & Tashak 1996 \\
\hline & & & Ust'-Kyakhta 17, Layer 5 & Bone & GIN-8493a & $12,100 \pm 80$ & Tashak 1996 \\
\hline \multirow[t]{6}{*}{86} & 51.63 & 108.17 & Varvarina Gora & Bone & AA-8893 & $>35,300 *$ & Goebel \& Aksenov 1995 \\
\hline & & & Varvarina Gora & Bone & AA- 8875 & $>34,050^{*}$ & Goebel \& Aksenov 1995 \\
\hline & & & Varvarina Gora & Bone & SOAN-1524 & $34,900 \pm 780$ & Bazarov et al. 1982 \\
\hline & & & Varvarina Gora & Bone & SOAN-850 & $30,600 \pm 500$ & Bazarov et al. 1982 \\
\hline & & & Varvarina Gora, Layer 2 & Bone & SOAN-3054 & $29,895 \pm 1,790$ & Lbova 1996a \\
\hline & & & Varvarina Gora, Layer 1 & Bone & SOAN-3053 & $17,035 \pm 400$ & Lbova 1996a \\
\hline \multirow[t]{10}{*}{87} & 51.77 & 108.33 & $\begin{array}{l}\text { Kamenka 1, } \\
\text { Component A }\end{array}$ & Bone & AA-26743 & $40,500 \pm 3,800^{*}$ & $\begin{array}{l}\text { Buerachnyi \& Lbova } \\
2000\end{array}$ \\
\hline & & & $\begin{array}{l}\text { Kamenka 1, } \\
\text { Component A }\end{array}$ & Charcoal & SOAN-3133 & $31,060 \pm 530$ & Lbova $1996 b$ \\
\hline & & & $\begin{array}{l}\text { Kamenka 1, } \\
\text { Component A }\end{array}$ & Bone & SOAN-3354 & $30,460 \pm 430$ & Lbova $1996 b$ \\
\hline & & & $\begin{array}{l}\text { Kamenka 1, } \\
\text { Component A }\end{array}$ & Bone & SOAN-2903 & $28,060 \pm 475$ & Lbova $1996 b$ \\
\hline & & & $\begin{array}{l}\text { Kamenka 1, } \\
\text { Component A }\end{array}$ & Bone & SOAN-3353 & $26,760 \pm 265$ & Lbova $1996 b$ \\
\hline & & & $\begin{array}{l}\text { Kamenka 1, } \\
\text { Component A }\end{array}$ & Bone & SOAN-3355 & $25,540 \pm 300$ & Kuzmin \& Orlova 1998 \\
\hline & & & $\begin{array}{l}\text { Kamenka 1, } \\
\text { Component A }\end{array}$ & Bone & SOAN-3031 & $24,625 \pm 190$ & Lbova 1996b \\
\hline & & & $\begin{array}{l}\text { Kamenka 1, } \\
\text { Component C }\end{array}$ & Bone & SOAN-3052 & $30,220 \pm 270$ & Lbova $1996 b$ \\
\hline & & & $\begin{array}{l}\text { Kamenka 1, } \\
\text { Component B }\end{array}$ & Bone & SOAN-2904 & $35,845 \pm 695$ & Lbova $1996 b$ \\
\hline & & & $\begin{array}{l}\text { Kamenka 1, } \\
\text { Component B }\end{array}$ & Bone & SOAN-3032 & $28,815 \pm 150$ & Lbova $1996 b$ \\
\hline \multirow[t]{6}{*}{88} & 51.22 & 109.33 & Tolbaga, Stratum 4 & Bone & SOAN-1522 & $34,860 \pm 2,100$ & Bazarov et al. 1982 \\
\hline & & & Tolbaga, Stratum 4 & Bone & SOAN-1523 & $27,210 \pm 300$ & Bazarov et al. 1982 \\
\hline & & & Tolbaga, Stratum 4 & Bone & AA- 8874 & $25,200 \pm 260 *$ & Goebel \& Waters 2000 \\
\hline & & & Tolbaga, Stratum 4 & Bone & AA-26740 & $29,200 \pm 1,000^{*}$ & Goebel \& Waters 2000 \\
\hline & & & Tolbaga, Stratum 4 & Bone & SOAN-3078 & $26,900 \pm 225$ & Sinitsyn \& Praslov 1997 \\
\hline & & & Tolbaga, Stratum 3 & Bone & SOAN-840 & $15,100 \pm 520$ & Bazarov et al. 1982 \\
\hline 89 & 51.78 & 108.80 & Mukhor-Tala 7 & Charcoal & SOAN-3468 & $11,630 \pm 300$ & Lbova et al. 1997 \\
\hline 90 & 50.62 & 107.80 & Kunalei, below Layer 3 & Humic acids & GIN-6124 & $21,100 \pm 300$ & Konstantinov 1994 \\
\hline 91 & 50.93 & 108.60 & Kandabaevo & Bone & SOAN-1625 & $38,460 \pm 1,100$ & Orlova 1995 \\
\hline 92 & 50.43 & 110.00 & Masterov Kliych, Layer 4 & Bone & AA- 8888 & $24,360 \pm 270 *$ & Meshcherin 1996 \\
\hline 93 & 50.18 & 108.55 & Priiskovaya & Bone & AA-8891 & $25,825 \pm 290^{*}$ & Kuzmin \& Orlova 1998 \\
\hline \multirow[t]{4}{*}{94} & 50.27 & 107.23 & Podzvonkaya & Bone & AA-26741 & $38,900 \pm 3,300^{*}$ & Klement'ev 2000 \\
\hline & & & Podzvonkaya & Bone & AA-26742 & $>36,800^{*}$ & Klement'ev 2000 \\
\hline & & & Podzvonkaya & Bone & SOAN-3404 & $26,000 \pm 1,000$ & Tashak 1996 \\
\hline & & & Podzvonkaya & Bone & SOAN-3350 & $22,675 \pm 265$ & Kuzmin \& Orlova 1998 \\
\hline 95 & 52.28 & 109.83 & Khotyk 3, Layer 2 & Charcoal & AA-32669 & $26,220 \pm 550 *$ & This paper \\
\hline \multirow[t]{9}{*}{96} & 50.17 & 108.50 & Studenoe 1, Layer 19/1 & Charcoal & GIN-6139 & $12,330 \pm 60$ & Konstantinov 1994 \\
\hline & & & Studenoe 1, Layer 18/2 & Charcoal & GIN-2947 & $12,800 \pm 400$ & Konstantinov 1994 \\
\hline & & & Studenoe 1, Layer 18/1 & Charcoal & LE-2061 & $13,430 \pm 150$ & Konstantinov 1994 \\
\hline & & & Studenoe 1, Layer 18/1 & Charcoal & GIN-2935 & $12,110 \pm 150$ & Konstantinov 1994 \\
\hline & & & Studenoe 1, Layer 17 & Charcoal & GIN-2934 & $12,140 \pm 150$ & Konstantinov 1994 \\
\hline & & & Studenoe 1, Layer 17 & Charcoal & GIN-2934a & $12,130 \pm 150$ & Konstantinov 1994 \\
\hline & & & Studenoe 1, Layer 15 & Charcoal & GIN-2931 & $14,900 \pm 2,000$ & Konstantinov 1994 \\
\hline & & & Studenoe 1, Layer 15 & Charcoal & LE-2062 & $12,290 \pm 130$ & Konstantinov 1994 \\
\hline & & & Studenoe 1, Layer 14 & Charcoal & GIN-2925 & $12,300 \pm 700$ & Konstantinov 1994 \\
\hline \multirow[t]{4}{*}{97} & 50.17 & 108.49 & Studenoe 2, Layer 5 & Charcoal & AA-23657 & $17,165 \pm 115^{*}$ & Goebel et al. 2000 \\
\hline & & & Studenoe 2, Layer 4/5 & Bone & AA-26739 & $18,830 \pm 300 *$ & Goebel et al. 2000 \\
\hline & & & $\begin{array}{l}\text { Studenoe 2, Layer } 4 / 5 \text {, } \\
\text { hearth } 1\end{array}$ & Charcoal & AA-23653 & $17,885 \pm 120 *$ & Goebel et al. 2000 \\
\hline & & & $\begin{array}{l}\text { Studenoe 2, Layer } 4 / 5 \text {, } \\
\text { hearth } 2\end{array}$ & Charcoal & AA-23655 & $17,225 \pm 115^{*}$ & Goebel et al. 2000 \\
\hline \multirow[t]{3}{*}{98} & & & Ust'-Menza 2, Layer 21 & Charcoal & GIN-5464 & $17,600 \pm 250$ & Konstantinov 1994 \\
\hline & & & Ust'-Menza 2, Layer 21 & Charcoal & GIN-5464A & $17,190 \pm 120$ & Konstantinov 1994 \\
\hline & & & Ust'-Menza 2, Layer 20 & Charcoal & GIN-5465 & $16,980 \pm 150$ & Konstantinov 1994 \\
\hline
\end{tabular}


Table 1 Results from the updated ${ }^{14} \mathrm{C}$ Database of the Siberian Paleolithic

\begin{tabular}{|c|c|c|c|c|c|c|c|}
\hline $\begin{array}{l}\text { Site } \\
\mathrm{nr}\end{array}$ & $\begin{array}{l}\text { Lat. } \\
\mathrm{N}\end{array}$ & $\begin{array}{l}\text { Long. } \\
\text { E }\end{array}$ & $\begin{array}{l}\text { Site name, } \\
\text { sample position }\end{array}$ & Material & Lab code & ${ }^{14} \mathrm{C}$ date $\mathrm{BP}$ & Reference \\
\hline & & & Ust'-Menza 2, Layer 17 & Charcoal & GIN-6117 & $16,900 \pm 500$ & Konstantinov 1994 \\
\hline & & & Ust'-Menza 2, Layer 17 & Charcoal & GIN-5478 & $15,400 \pm 400$ & Konstantinov 1994 \\
\hline & & & Ust'-Menza 2, Layer 11 & Charcoal & GIN-6116 & $14,830 \pm 390$ & Konstantinov 1994 \\
\hline 99 & 50.21 & 108.62 & Ust'-Menza 1, Layer 14 & Charcoal & GIN-7161 & $11,820 \pm 120$ & Konstantinov 1994 \\
\hline 100 & 50.13 & 108.82 & $\begin{array}{l}\text { Kosaya Shivera 1, } \\
\text { Layer } 14\end{array}$ & Charcoal & GIN-6123 & $12,070 \pm 300$ & Konstantinov 1994 \\
\hline 13 & & & Arta 2, Layer 3 & Charcoal & LE-2966 & $23,200 \pm 2,000$ & $\begin{array}{l}\text { Kirillov \& Kasparov } \\
1990\end{array}$ \\
\hline \multirow[t]{4}{*}{101} & 52.02 & 113.43 & Sokhatino 4, Layer 8 & Bone & LE-3653 & $16,970 \pm 720$ & $\begin{array}{l}\text { Lisitsyn \& Svezhentsev } \\
1997\end{array}$ \\
\hline & & & Sokhatino 4, Layer 7 & Bone & LE-3647 & $16,820 \pm 390$ & $\begin{array}{l}\text { Kirillov \& Cherensh- } \\
\text { chikov } 1996\end{array}$ \\
\hline & & & Sokhatino 4, Layer 6 & Bone & LE-3652 & $15,820 \pm 300$ & $\begin{array}{l}\text { Lisitsyn \& Svezhentsev } \\
1997\end{array}$ \\
\hline & & & Sokhatino 4 & Charcoal & SOAN-1138 & $26,110 \pm 150$ & $\begin{array}{l}\text { Okladnikov \& Kirillov } \\
1980\end{array}$ \\
\hline \multicolumn{8}{|c|}{ The Russian Far East } \\
\hline \multirow[t]{5}{*}{102} & 50.30 & 130.32 & Malye Kuruktachi & Charcoal & SOAN-3287 & $14,200 \pm 130$ & Kuzmin et al. 1998a \\
\hline & & & Malye Kuruktachi & Charcoal & AA-13399 & $13,815 \pm 150 *$ & Kuzmin et al. 1998a \\
\hline & & & Malye Kuruktachi & Charcoal & AA-13398 & $13,310 \pm 105^{*}$ & Kuzmin et al. 1998a \\
\hline & & & Malye Kuruktachi & Charcoal & AA-17212 & $12,485 \pm 80^{*}$ & Kuzmin et al. 1998a \\
\hline & & & Malye Kuruktachi & Charcoal & AA- 23128 & $12,010 \pm 75^{*}$ & Kuzmin et al. 1998a \\
\hline 103 & 51.92 & 129.30 & Ust'-Ulma 1, Layer 2 & Charcoal & SOAN-2619 & $19,360 \pm 65$ & $\begin{array}{l}\text { Derevianko \& Zenin } \\
1995 \mathrm{~b}\end{array}$ \\
\hline \multirow[t]{11}{*}{104} & 42.92 & 133.05 & $\begin{array}{l}\text { Geographical Society } \\
\text { Cave }\end{array}$ & Bone & AA-37070 & $>40,000 *$ & This paper \\
\hline & & & $\begin{array}{l}\text { Geographical Society } \\
\text { Cave }\end{array}$ & Bone & AA-37068 & $>39,000^{*}$ & This paper \\
\hline & & & $\begin{array}{l}\text { Geographical Society } \\
\text { Cave }\end{array}$ & Bone & AA-37071 & $>38,000^{*}$ & This paper \\
\hline & & & $\begin{array}{l}\text { Geographical Society } \\
\text { Cave }\end{array}$ & Bone & AA-34074 & $>38,000^{*}$ & This paper \\
\hline & & & $\begin{array}{l}\text { Geographical Society } \\
\text { Cave }\end{array}$ & Bone & AA-37072 & $>37,000^{*}$ & This paper \\
\hline & & & $\begin{array}{l}\text { Geographical Society } \\
\text { Cave }\end{array}$ & Bone & AA-37073 & $>36,000^{*}$ & This paper \\
\hline & & & $\begin{array}{l}\text { Geographical Society } \\
\text { Cave }\end{array}$ & Bone & AA-37069 & $35,100 \pm 1,900 *$ & This paper \\
\hline & & & $\begin{array}{l}\text { Geographical Society } \\
\text { Cave }\end{array}$ & Bone & AA-38230 & $34,510 \pm 1,800 *$ & This paper \\
\hline & & & $\begin{array}{l}\text { Geographical Society } \\
\text { Cave }\end{array}$ & Bone & AA-37183 & $34,400 \pm 1,800 *$ & This paper \\
\hline & & & $\begin{array}{l}\text { Geographical Society } \\
\text { Cave }\end{array}$ & Bone & AA-38229 & $34,300 \pm 1,700^{*}$ & This paper \\
\hline & & & $\begin{array}{l}\text { Geographical Society } \\
\text { Cave }\end{array}$ & Bone & IGAN-341 & $32,570 \pm 1,510$ & Kuz'min 1994 \\
\hline \multirow[t]{4}{*}{105} & 44.27 & 135.30 & Suvorovo 4 & Charcoal & AA-9463 & $15,105 \pm 100 *$ & $\begin{array}{l}\text { Krupianko \& Tabarev } \\
2001\end{array}$ \\
\hline & & & Suvorovo 4 & Charcoal & $\mathrm{Ki}-3502$ & $15,300 \pm 140$ & $\begin{array}{l}\text { Krupianko \& Tabarev } \\
2001\end{array}$ \\
\hline & & & Suvorovo 4 & Charcoal & AA-36625 & $15,340 \pm 90 *$ & $\begin{array}{l}\text { Krupianko \& Tabarev } \\
2001\end{array}$ \\
\hline & & & Suvorovo 4 & Charcoal & AA-36626 & $15,900 \pm 120 *$ & $\begin{array}{l}\text { Krupianko \& Tabarev } \\
2001\end{array}$ \\
\hline \multirow[t]{3}{*}{106} & 43.95 & 132.40 & $\begin{array}{l}\text { Gorbatka } 3 \text { (below cul- } \\
\text { tural layer) }\end{array}$ & Organics & SOAN-1922 & $13,500 \pm 200$ & Kuznetsov 1992 \\
\hline & & & Ogonki 5, Layer 2b & Charcoal & AA-20864 & $19,320 \pm 145^{*}$ & Kuzmin et al. 1998b \\
\hline & & & Ogonki 5 , Layer $2 b$ & Charcoal & AA-25434 & $18,920 \pm 150 *$ & Kuzmin et al. 1998b \\
\hline 107 & 46.78 & 142.43 & Ogonki 5 , Layer $2 b$ & Charcoal & AA-23137 & $17,860 \pm 120 *$ & Kuzmin et al. $1998 b$ \\
\hline \multicolumn{8}{|c|}{ The Yakutia and Northeastern Siberia } \\
\hline 108 & 59.99 & 117.35 & Khaergas Cave, Layer 6 & Bone & IM-887 & $16,000 \pm 300$ & Cherosov 1988 \\
\hline 109 & 60.52 & 135.13 & $\begin{array}{l}\text { Ezhantsy, Layer } 3 \text { (depth } \\
0.6 \text { to } 1.0 \mathrm{~m} \text { ) }\end{array}$ & Bone & IM-459 & $17,150 \pm 345$ & Kostiukevich et al. 1980 \\
\hline 110 & 59.65 & 133.12 & $\begin{array}{l}\text { Ust'-Mil 2, Stratum } 5 \\
\text { (below cultural layer) }\end{array}$ & Wood & LE-955 & $35,600 \pm 900$ & Mochanov 1977 \\
\hline
\end{tabular}


Table 1 Results from the updated ${ }^{14} \mathrm{C}$ Database of the Siberian Paleolithic

\begin{tabular}{|c|c|c|c|c|c|c|c|}
\hline $\begin{array}{l}\text { Site } \\
\mathrm{nr}\end{array}$ & $\begin{array}{l}\text { Lat. } \\
\mathrm{N}\end{array}$ & $\begin{array}{l}\text { Long. } \\
\text { E }\end{array}$ & $\begin{array}{l}\text { Site name, } \\
\text { sample position }\end{array}$ & Material & Lab code & ${ }^{14} \mathrm{C}$ date $\mathrm{BP}$ & Reference \\
\hline & & & $\begin{array}{l}\text { Ust'-Mil 2, Stratum 4, } \\
\text { middle part }\end{array}$ & Wood & LE-954 & $35,400 \pm 600$ & Mochanov 1977 \\
\hline & & & $\begin{array}{l}\text { Ust'-Mil 2, Stratum 4, } \\
\text { middle part }\end{array}$ & Wood & LE-1000 & $33,333 \pm 500$ & Mochanov 1977 \\
\hline & & & $\begin{array}{l}\text { Ust'-Mil 2, Stratum 4, } \\
\text { middle part }\end{array}$ & Wood & LE-1101 & $30,000 \pm 500$ & Mochanov 1977 \\
\hline & & & $\begin{array}{l}\text { Ust'-Mil 2, Stratum 4, } \\
\text { upper part }\end{array}$ & Wood & LE-999 & $23,500 \pm 500$ & Mochanov 1977 \\
\hline & & & Ust'-Mil 2, Stratum 3 & Wood & LE-953 & $12,200 \pm 170$ & Mochanov 1977 \\
\hline 111 & 63.12 & 133.60 & Ikhine 1, Layer 2 & Bone & IM-452 & $16,660 \pm 270$ & Kuzmin \& Orlova 1998 \\
\hline \multirow[t]{13}{*}{112} & 63.12 & 133.62 & Ikhine 2, Layer $2 \mathrm{~g}$ & Wood & IM-206 & $27,800 \pm 500$ & Mochanov 1977 \\
\hline & & & Ikhine 2, Layer 2v & Wood & GIN-1020 & $31,200 \pm 500$ & Mochanov 1977 \\
\hline & & & Ikhine 2, Layer 2v & Wood & IM-201 & $26,600 \pm 900$ & Mochanov 1977 \\
\hline & & & Ikhine 2, Layer 2v & Wood & IM-201 & $26,500 \pm 900$ & Mochanov 1977 \\
\hline & & & Ikhine 2, Layer $2 \mathrm{v}$ & Bone & IM-239 & $26,030 \pm 200$ & Mochanov 1977 \\
\hline & & & Ikhine 2, Layer 2b & Wood & GIN-1019 & $30,200 \pm 300$ & Mochanov 1977 \\
\hline & & & Ikhine 2, Layer 2b & Wood & IM-205 & $27,400 \pm 800$ & Mochanov 1977 \\
\hline & & & Ikhine 2, Layer 2b & Wood & IM-155 & $24,600 \pm 380$ & Mochanov 1977 \\
\hline & & & Ikhine 2, Layer 2b & Wood & IM-203 & $24,500 \pm 480$ & Mochanov 1977 \\
\hline & & & Ikhine 2, Layer 2b & Wood & LE-1131 & $24,330 \pm 200$ & Mochanov 1977 \\
\hline & & & Ikhine 2, layer unknown & Bone & SOAN-3185 & $20,080 \pm 150$ & Kuzmin \& Orlova 1998 \\
\hline & & & Ikhine 2, layer unknown & Bone & SOAN-3186 & $19,695 \pm 100$ & Kuzmin \& Orlova 1998 \\
\hline & & & Ikhine 2, layer unknown & Bone & SOAN-3187 & $15,780 \pm 70$ & Orlova et al. 2000b \\
\hline \multirow[t]{4}{*}{113} & 60.35 & 134.45 & $\begin{array}{l}\text { Verkhne-Troitskaya, } \\
\text { Layer } 6\end{array}$ & Wood & LE-905 & $18,300 \pm 180$ & Mochanov 1977 \\
\hline & & & $\begin{array}{l}\text { Verkhne-Troitskaya, } \\
\text { Layer } 6 \text { (above artifacts) }\end{array}$ & Wood & LE-906 & $17,680 \pm 250$ & Mochanov 1977 \\
\hline & & & $\begin{array}{l}\text { Verkhne-Troitskaya, } \\
\text { Layer } 6 \text { (above artifacts) }\end{array}$ & Charcoal & GIN-626 & $15,950 \pm 250$ & Mochanov 1977 \\
\hline & & & $\begin{array}{l}\text { Verkhne-Troitskaya, } \\
\text { Layer } 6 \text { (above artifacts) }\end{array}$ & Wood & LE-864 & $14,530 \pm 160$ & Mochanov 1977 \\
\hline \multirow[t]{8}{*}{114} & 59.30 & 132.60 & $\begin{array}{l}\text { Dyuktai Cave, } \\
\text { Depth } 2.7 \mathrm{~m}\end{array}$ & Bone & IM-462 & $12,520 \pm 259$ & Kostiukevich et al. 1984 \\
\hline & & & Dyuktai Cave, Layer $7 \mathrm{v}$ & Wood & LE-908 & $13,110 \pm 90$ & Mochanov 1977 \\
\hline & & & Dyuktai Cave, Layer 7b & Charcoal & GIN-404 & $14,000 \pm 100$ & Mochanov 1977 \\
\hline & & & Dyuktai Cave, Layer 7b & Charcoal & LE-784 & $13,070 \pm 90$ & Mochanov 1977 \\
\hline & & & Dyuktai Cave, Layer 7b & Charcoal & LE-860 & $12,960 \pm 120$ & Mochanov 1977 \\
\hline & & & Dyuktai Cave, Layer 7a & Charcoal & GIN-405 & $13,200 \pm 250$ & Mochanov 1977 \\
\hline & & & Dyuktai Cave, Layer 7a & Wood & IM-462 & $12,520 \pm 260$ & Mochanov 1977 \\
\hline & & & Dyuktai Cave, Layer 7a & Wood & LE-907 & $12,100 \pm 120$ & Mochanov 1977 \\
\hline \multirow[t]{2}{*}{115} & 70.43 & 143.95 & Berelekh & Wood & IM-152 & $13,420 \pm 200$ & Mochanov 1977 \\
\hline & & & Berelekh & Wood & GIN-1021 & $12,930 \pm 80$ & Mochanov 1977 \\
\hline \multirow[t]{3}{*}{116} & 56.17 & 159.97 & Ushki 1, Layer 7 & Charcoal & GIN-167 & $14,300 \pm 200$ & Dikov 1996a \\
\hline & & & Ushki 1, Layer 7 & Charcoal & GIN-167 & $13,600 \pm 250$ & Dikov 1977 \\
\hline & & & Ushki 1, Layer 6a & Charcoal & LE-4185 & $13,800 \pm 600$ & $\begin{array}{l}\text { Lisitsyn \& Svezhentsev } \\
1997\end{array}$ \\
\hline 117 & 61.63 & 149.52 & Siberdik, Layer 3 & Charcoal & MAG-916 & $13,225 \pm 230$ & Lozhkin \& Trumpe 1990 \\
\hline
\end{tabular}

